\title{
El pueblo en tiempos de Jesús. La no-historia del pueblo (o el 'reverso de la historia')
}

\author{
CARLOS BRAVO GALLARDO, \\ Guadalajara, México.
}

La historia tiene un reverso que no ha sido escrito aún. Ni lo será. Para la historia oficial no cuenta el pueblo, ni para los proyectos de los grupos dominantes. Si acaso cuenta como mano de obra de sus construcciones, como consumidores de sus productos o, en último término, pero no menos importante, como los millones de muertos sobre quienes se edifican las victorias y los imperios.

El pueblo no contaba para los romanos ni para los grupos dominantes. Pero hubo un hombre que se consagró a la causa del pueblo de una manera que resultó preocupante para sus familiares y también para los poderosos. En torno a él se crearon grandes expectativas mesiánicas. La insistencia con que lo seguía la gente le resultaba incluso peligrosa y amenazante aun fisicamente (Mc. 3,9-10; 4,1; 5,24); pero de tal manera estaba entregado al pueblo que no encontraba tiempo ni para comer (Mc. 3,20; 6,31).

Lo que quizá más desconcertaba era que Jesús no buscaba en el pueblo nada para sí; no lo utilizaba, no lo manipulaba; simplemente lo amaba y quería que viviera en plenitud. El pueblo contaba para el, y en función suya hacia sus planes y los modificaba si era necesario. Nacido en el seno del pueblo, se había identificado con su historia de despojo; con su acción pretendia provocar un cambio en su situación de no-vida y no-historia, porque su más honda convicción era que Dios estaba por irrumpir en la historia con un reinado en favor de los marginados, los rechazados todos de la sociedad. A ellos se sabe enviado (Lc. 4, 18-19). Y por ellos se enfrentará a los poderosos hasta el extremo del conflicto; hasta la muerte misma llegará por la causa del pueblo, porque en ella, en que el pueblo viva, se condensa y se cumple en la historia la causa del Padre.

\section{La condición del pueblo. "Mi padre fue un arameo errante condenado al fracaso."}

La situación del pueblo es, pues, fundamental para entender a Jesús. El problema es el acceso a la situación del pueblo. Porque no es éste quien escribe 
la historia. Sin embargo, en torno a él se tejen diferentes prácticas: los grupos sociales se relacionan con el pueblo y en esa relación proyectan tanto su propia ideología y sus planes como lo que el pueblo representa para ellos. Y el acceso al conocimiento de esas práclicas si es posible. Sobre ellas hay un rico material bibliográricol en los estudios sobre la situación de Palestina en tiempos de Jesús. Pero en su estudio hemos quericlo lener como hilo conductor la situación del pueblo. Y el telón de fondo es la situación del pueblo de Israel a lo largo de su historia.

La condición del pueblo es la consecuencia o contrapartida de las práciicas de los grupos dominantes. Por eso un momento importante de este estudio será la caracterización de los principales grupos judios y la determinación de las diferencias que los enfrentan con el pueblo y entre si; en esa Irama social se encuenıra la razón de la "condición" del pueblo. Como esquema analitico seguimos el más común: la división de la sociedad y sus aclividades en tres instancias o sectores interrelacionados entre sí: la instancia económica (referente a las actividades encaminadas a producir la base material indispensable para la existencia de la sociedad, y a las relaciones de producción, distribución y apropiación de lo producido para la vida); la instancia politica (la organización de las relaciones dentro de la sociedad de forma que se garantice el funcionamiento del esquema de producción de la base material; en esta instancia se incluye la manera como se organiza y distribuye el poder dentro de la sociedad, y la coacción que eventualmente se necesite ejercer para mantener el sistema de producción y apropiación); y la instancia ideológica (las actividades de tipo analitico, cultural, legislativo, simbólico y ritual encaminadas a reforzar y expresar la identidad, el asentamiento y la aceptación de la organización social y su legitimidad). En esta última instancia serán especialmente importantes dos aspectos: el de los sistemas de leyes, que norman las relaciones y conductas en cuanto donadoras de vida o de muerte para el pueblo, y el del culto religioso, que norma y organiza la expresión simbólica y ritual de lo más profundo del hombre: el mundo del sentido de la existencia. ${ }^{2}$

En cada una de las instancias haremos una comparación entre la situación del pueblo a través de la historia y la situación en tiempos de Jesús.

\section{a) La instancia económica}

\section{1) El pueblo a través de la historia}

La referencia a la tierra es fundamental para el pueblo de lsrael; es el problema crucial, porque es la garantia de su existencia como pueblo. La posesión de la tierra la vive como un hecho religioso.

Prometida y dada por Dios en función de la vida, abre al pueblo al futuro y a la esperanza que nace de la fe en la fidelidad de Yahvé, dueño de toda la tierra. Esta es condición de libertad para la alianza y para poder ser pueblo; por eso experimenta su posesión como bendición de Yahvé, como vida y felicidad; y la desposesión la ve como castigo por la infidelidad, como maldición y muerte. 
En torno a su posesión ha ido cristalizando la idemlidad de un pueblo hermanado en igualdad por el derecho compartido a una tierra común dada a todos por igual. En corno a la delensa de la vida y a la ayuda mutua se ha identificado como pueblo elegido por Yahvé, y en ıodo esto experimenta la protección ranto de Dios como de la comunidad.

Pero esa tierra no ha sido poseida sin violencia. Es una ticrra conquisıada por medio de una guerra contra sus ocupantes anteriores (los señores cananeos) quienes habian organizado una sociedad bajo el signo de la dominación leudal de la ciudad sobre el campo, prolongación, de hecho, del imperio egipcio de cuyo esclavismo politico y laboral habian escapado. Es una lierra delendida contra los filistcos y cananeos, que tratan de reconquistarla; cs una tierra cuyos límiles se amplian en liempos de los reyes de Judá e Israel, originando un proyecto imperial de dominación judía sobre los pueblos vecinos; es una tierra codiciada por los imperios de turno para sus proyectos expansionistas; contra ellos el pueblo organizará luchas de resistencia y de reconquista de la independencia, frente a las dominaciones politica y económica.

No sólo se ha generado violencia hacia fuera por causa de la tierra; tambièn hacia dentro Israel vive la violencia en torno a la tierra: a pesar de que el derecho yahvista sobre la tierra hace imprescriptible la propiedad familiar, el pueblo ha sido despojado de ella en benelicio de la corte y de los ricos; la acumulación de tierras ha constituido latifundios contrarios al plan de igualdad que Yahvé tiene para su pueblo; también ha perdido el pueblo la propiedad de la tierra por causa del empobrecimiento y deudas que originan regimenes tributarios internos (corte real) y externos (imperios). Por ello se han originado situaciones de esclavismo laboral. Los profetas siempre han denunciado la injusticia de esas situaciones.

\section{2) El pueblo en tiempos de Jesús}

Pueblo desposeido: la tierra. De alguna manera se reproduce la situación anterior al éxodo (y a la pascua), de esclavismo y despojo; pero ahora es en su propia tierra donde viven el despojo y la dominación, de parte de los romanos. Unas cuantas familias privilegiadas la poseen: la corte real, la "burocracia" y la nobleza laica y sacerdotal; a ellas se les ha vendido o se les ha dado en concesión a cambio de fidelidad no ya al proyecto de Yahvé, sino al proyecto del imperio romano; eso ha reforzado la desigualdad de la estructura social: pocas familias tienen muchas tierras ${ }^{3}$ y viven en altos niveles de lujo y dispendio, ${ }^{4}$ y grandes mayorias están privadas del acceso a la propiedad de la tierra.

Pueblo explotado: el trabajo. La carencia de tierra de las mayorias hace que tengan que vender su trabajo para subsistir; tienen que alquilarse como trabajadores eventuales e incluso como esclavos. Hay campesinos, de los cuales una minoria trabaja su pequeña tierra propia, y los más como eventuales en tierras de latifundistas que viven en las ciudades, ausentes del campo y disfrutando de lo que la tierra les da por el sudor de otros hombres.

Jerusalén concentra la mayor capacidad de mercado de trabajo, tanto en la construcción (de obras públicas y cortesanas y del templo particularmente) 
como en los servicios en torno al culto del templo (aprovisionamiento, comercio, transporte, hospedaje ${ }^{5}$ ). Muchos oficios son considerados impuros. Se consideran oficios "de ladrones" los relacionados con el transporte, ${ }^{6}$ los pastores, los tenderos, los médicos y los carniceros; se ven como sospechosos los trabajos en los que hay relación con mujeres y, por tanto, con peligro de inmo-

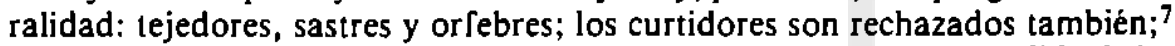
hay oficios considerados como proscritos de iure, y conllevan la pérdida de los derechos civiles y políticos: son los que se consideran directamente involucrados con el fraude, como los jugadores de dados, usureros, comerciantes de productos del año sabático, recaudadores de impuestos y titulares de los puestos de cambio (publicanos); también los pastores eran incluidos en este capitulo. ${ }^{8}$ A todos éstos se les tenia como ilegales y proscritos, incapacitados como testigos (como los esclavos), privados incluso de los derechos que podría tener un bastardo judio. ${ }^{9}$ En este mismo capítulo habría que añadir a las prostitutas.

Pueblo empobrecido: desempleo, mendicidad, hambre. Pero hay que tener en cuenta la escasez de fuentes de trabajo (fuera de la manufactura de algunos productos) y que en el campo el trabajo es eventual. Podríamos caracterizar la situación como de desempleo generalizado, que empuja a muchos hombres a la mendicidad. El cuadro descrito en los sinópticos (preocupación por el mínimo vital, prisión por deudas, desempleo, contraste entre pobres y ricos) es rigurosamente histórico; el hambre y la mendicidad alcanzan a amplios estratos de población del imperio romano en el S.I. ${ }^{10}$ No será extraño encontrarse con situaciones de hambre incluso entre sacerdotes pobres, por causa de la explotación de parte de los grandes sacerdotes. ${ }^{11}$

Finalmente hay que tener en cuenta los fenómenos de depresión económica, probablemente más fuerte en el campo que en la ciudad ${ }^{12}$ y la inflación y carestia, mayor en la ciudad que en el campo. ${ }^{13}$

Pueblo despojado: los impuestos. Sobre el pueblo gravita la fuerte carga de los impuestos civiles y religiosos. Ha de pagar la esclavicud a Roma, el lujo de la corte real y la consirucción y funcionamiento del templo. ${ }^{14}$

Roma cobra impuestos a todo el territorio dominado; la corte de Herodes y la clase adinerada vivian en grandes lujos, y sus finanzas tenian que apoyarse en los impuestos del pueblo. De acuerdo a los datos de Flavio Josefo, los ingresos de Herodes deben calcularse en alrededor de 1.000 talentos, y 1.200 para Herodes Agripa I; ${ }^{15}$ pero ni con eso pueden hacer frente a sus gastos superfluos.

En el terreno religioso hay que mencionar el diezmo para los sacerdotes, el segundo diezmo, que debía gastarse en Jerusalén, la compra de animales para sacrificios de purificación y los destinados a la pascua, (cuyos precios se encarecerian de acuerdo a la demanda, 16 los donativos y el impuesto para la construcción del templo (un didracma = dos denarios).

La incapacidad de pago podia preveerse dado el despojo de tierras que sufrió el pueblo. ${ }^{17}$ "A la vista de las manifestaciones de protesta tan largamente mantenidas, se temió entonces que el abandono de la agricultura iba a 
traer como consecuencia inevitable el bandolerismo, porque ellos (es decir, los campesinos participantes en la manifestación) no podrian pagar los impuestos;" 18 las deudas obligarán a muchos a abandonar la tierra, y aun a venderse como esclavos. La misma dificultad de pago se percibe detrás de la reiterada exigencia de los fariseos, que presionan al pueblo para el pago de los diezmos, y detrás de la situación de pobreza en que viven muchos sacerdotes. 19

Podria sintetizarse la situación económica del pueblo en los siguientes rasgos: es un pueblo despojado, explotado, tributario, empobrecido, sin espacio vilal y sin permiso para vivir. ${ }^{20}$ Lo que hace menos dura la situación de vida amenazada es la solidaridad existente entre el pueblo. ${ }^{2 L}$

\section{b) La instancis política}

\section{1) El pueblo a través de la historia}

En lo político, la referencia fundamental del pueblo de Israel es el proyecto yahvista igualitario. El hecho religioso de la alianza de Dios con el pueblo lo lleva a la experiencia de la libertad como condición de la identidad judia; libertad que pasa necesariamente por el momento político de la liberación respecto de cualquier dominación, y de la resistencia contra los proyectos imperialistas. Por la alianza, Dios ha hecho responsable al pueblo, de la creación de una estructura social que posibilita las relaciones justas entre los hombres.

Sin embargo, el pueblo ha vivido la experiencia de la perversión del poder a través de la historia entera. La corrupción de los hijos de Samuel, puestos por él como jueces, lo llevaron a buscar en la monarquía una estructura que garantizara mejor la vida del pueblo (1 Sam. 8), pero el resultado fue una historia constante de privilegios reales, de acumulación de tierras, riquezas, lujo, poder, a costa del pueblo. Cuando el poder estuvo en el sur (sobre todo con Salomón y Roboam) la opresión sobre las tribus del norte fue causa de la ruplura de la unidad interna tribal, apenas en gestación frente a las amenazas comunes; posteriormente la opresión real se siguió manifestando en los impuestos, en la leva militar, en los trabajos forzados para las obras reales. EI poder interno de Israel se ha pervertido y ha llevado a la violación de los derechos fundamentales de la alianza: los derechos de Dios (por la idolatría y el culto a los baales y por las alianzas politicas que hacen poner la confianza en poderes ajenos a Israel y no en Yahvé) y los derechos del pobre (por la desigualdad e injusticia establecidas, en las que el estatuto yahvista se viola sistemáticamente).

Esto será visıo por los profetas como causa de las sucesivas dominaciones que padecerá Israel en castigo a su infidelidad: en tiempos de los jueces y los primeros reyes serán las amenazas filisteas y cananeas; en el 721 , la dominación asiria con el destierro y la destrucción del reino del norte; en el 598, la dominación babilonia, que arrasó con las esperanzas de Judá de librarse del destierro; luego la dominación persa, la más benigna de todas, que permitirá el retorno en el 538; los griegos dominarán a partir del 336 (Alejandro Magno); a su muerte, el dominio sobre Palestina regresará a Egipto, a manos de los Ptolomeos, sus sucesores, para pasar luego, en el 198, al poder de los Seléucidas. 
Esa dominación llega a su punto más critico durante el reinado de Antioco IV (175-163) cuya persecución religiosa desencadena la reacción guerrera de los macabeos. La independencia se conseguirá el 160, con Jonalán, hermano de Judas Macabeo y sucesor suyo, y durará alrededor de un siglo; pero entonces mismo empezará la corrupción del poder, al acaparar aquél la dignidad sacerdotal y el poder político al mismo liempo. Esa situación durará hasta que los Asmoneos pierdan el poder, en parte por intrigas internas, en parte (y principalmente) por el advenimiento del nuevo imperio en lurno, el romano, que en el 63 se apodera de Palestina. Y con el reinado de la familia de Herodes, dependiente de Roma, seguirá la cruel experiencia de perversión del poder. Así llegamos a liempos de Jesús.

\section{2) El pueblo en liempos de Jesús}

Pueblo dominado. Sobre él se ejerce una doble dominación política: la romana y la herodiana. El nacimiento de Jesús sucede aún en vida de Herodes el Grande, quien muere el 4 a. C. ${ }^{22}$ Esa dominación implica la privación de la capacidad de gobierno propio. Además Palestina se convierte en tierra de paso para los ejércitos romanos, lo cual supone también la contaminación ritual de la tierra de Israel por los paganos.

Pueblo traicionado por sus jefes. Esa situación de dominación se agrava más aún por la apariencia de gobierno independiente; por un lado, la corıe real, despreciada por su origen, ${ }^{23}$ odiada por el pueblo y con una vida de lujo que es un insulto al pueblo, dada la situación de pobreza generalizada 24 y por otro el Sanhedrin, con el gobierno ordinario del pueblo judio, pero cuyos jefes son aliados de Roma para mantener la pax romana, de la que sus propios intereses forman parte sustancial. Esa apariencia de gobierno propio oculta la verdad: Israsl ya no es un gobierno teocrático (regido por Yahvé); no liene más rey que César, como lo confiesan ante Pilato los miembros del Sanhedrin, leales servidores del emperador romano $(\mathrm{Jn} .19,15)$, comprados por las concesiones que se les hacen, y amantes de la Pax "ya sólo por consideración de sus propiedades" 25 y cómplices de los romanos en el despojo del pueblo. Esıo resulta tanto más grave cuando que el rejnado exclusivo de Dios sobre el pueblo es un elemento nuclear de la fe de Israel, que sus jefes han hipotecado en beneficio de su situación privilegiada.

Pueblo dividido. De alguna manera sigue la división sur/norte, quizá ahora mejor caracterizada como enfrentamiento centro (jerusalén) / márgenes (provincias y campo). Jerusalén acapara privilegios romanos y fuentes de trabajo, latifundios y riqueza, asi como los beneficios económicos de las peregrinaciones religiosas y el poder que implica ser el centro ideológico-religioso de toda Judea; desprecia particularmente a Samaria (por impuros y 'herejes') y a Galilea (por la mezcla racial que los hace impuros, y por los movimientos de resistencia que alteran la Pax). Por ıodo eso Jerusalén (el centro) será conservadora y contraria al cambio. ${ }^{26}$ Además, en ella viven los terratenientes, ausentes de sus viñas y campos, lo cual atiza el resentimiento de los campesinos conlra la ciudad. 27 
Pueblo reprimido y en resistencia. La explotación que pesa sobre el pueblo ha provocado acciones de resistencia, sofocadas sangrientamente por el poder romano. Los zelotas surgen de la base popular, motivados fuertemente por la fe en el dominio exclusivo de Dios sobre el pueblo y se apoyan fuertemente en las ideas apocalipticas que proclaman llegado el momento del triunfo de Yahvé sobre los enemigos del pueblo. Creen llegado el tiempo de la reconquista, que exige la resistencia activa para acelerar la realización del proyecto yahvista de igualdad; asi finalmente regresará Israel a su lugar privilegiado sobre las naciones paganas. En el campo, la insatisfacción causada por la depresión económica, y la propagación de las ideas apocalipticas, fuera del control de los saduceos, hacen a la población más pronta a colaborar con la resistencia y agitación zelota; la afluencia en Jerusalén con motivo de las fiestas será ocasión propicia para que se manifieste el resentimiento de los provincianos contra Roma y contra la ciudad. ${ }^{28}$ La teologia esenia jugará un papel importante en esas expectativas apocalipticas, aunque las viven desde una concepción elitista que nos hace esperar pasivamente la llegada del momento en que Dios mismo desencadene el combate escatológico final contra el reino de las tinieblas, y la victoria del reino de la luz, del que ellos serán los destinatarios privilegiados. En ambas concepciones (zelota y esenia) la llegada del reino de Dios implica la negación del dominio romano, dé la corte herodiana y de la aristocracia saducea (laica y sacerdotal) en el poder.

La situación podria sintetizarse en los siguientes rasgos: es un pueblo dominado, en ocasiones reprimido con crueldad, al que no se responde en sus justas aspiraciones; sin poder de participación y decisión en su propio destino; agitado en esos momentos por expectativas mesiánicas de liberación, pero también con el fatalismo nacido de las frustraciones producidas en experiencias anteriores a lo largo de la historia.

\section{c) La instancia ideológica}

\section{1) El pueblo a través de la historia}

El elemento nuclear de la fe de Israel es la elección de parte de Dios. Son su pueblo. En torno a la elección engarzarán todos los demás temas clave de la teología de lsrael: la promesa, la liberación y el éxodo, la alianza, las leyes, la unidad tribal y, posteriormente, la monarquia, la sucesión davídica, el sacerdocio, el templo y el culto, el mesianismo.

La elección implica de parte de Dios la misericordia y la gratitud. Se ha fijado en Israel no en ątención a méritos, sino porque a Yahvé le afecta el sufrimiento humano y le importa que la historia de los oprimidos injustamente cambie a favor de ellos; que se les trate y ame. El los ama y trata. Por eso la liberación política la vivirá Israel como experiencia religiosa de quien es Dios y como condición para la alianza: sólo con un pueblo libre puede asociarse Dios.

De esa alianza se derivan obligaciones morales para el pueblo de Israel; en sus leyes se concretará el designio o voluntad de Dios respecto de las relaciones que deben regir la vida del pueblo: relaciones de los hombres con Dios, entre sí 
y con el mundo. En las leyes se concretará en qué se juega el hombre la vida o la muerte, su existencia o su disolución como pueblo de Dios.

Resalta particularmente en la constitución del pueblo su carácter comunitario contrario al individualismo del pensamiento occidental: es el pueblo el sujeto de la alianza; por ello tiene una dimensión histórica, por la que se sabe en continuidad con los patriarcas y en solidaridad de destino con los que en el futuro serán herederos de la elección. Todos forman una "persona corporativa," un "gran yo," que conserva memoria histórica de su identidad.

Esta continuidad "cuasi personal" de Israel es lo que dará al culto su dimensión de memorial, es decir, de celebración de las maravillas que Yahvé hace "hoy" en favor del pueblo. La pascua celebra la libertad que hoy se tiene gracias a la identidad que hay entre "nosotros" y "nuestros padres;" por eso pueden decir que "hoy" nos liberó Yahvé de Egipto: la liberación realizada "entonces" en favor de nuestros padres sigue actuando en la libertad que "hoy" nosotros tenemos; la libertad de hoy empezó entonces.

En el terreno de las leyes existe una pugna entre dos concepciones: la que considera que la justicia y la misericordia es la cuestión de vida o muerte para el pueblo, y la que considera que lo que es cuestión de vida o muerte es la pureza ritual y el culto en el templo; la primera da primacía a la gratuidad, la segunda, al mérito; la primera origina a igualdad, la segunda fomenta la diferencia y la separación. La consecuencia del predominio de la segunda, en manos de los sacerdotes primero, y después, de los fariseos y sus escribas, que con sus 613 mandamientos producirán una "inflación" de la pureza, será la estratificación socio-religiosa que caracteriza la sociedad judia en tiempos de Jesús. Su fundamento es una concepción de la santidad de Dios como separación y distancia del pueblo impuro; implica la imagen de un Dios airado, cuya cercania es mortal para el hombre. Para "aplacarlo" se necesitan sacrificios, por un lado, y mediadores, por otro, que protejan al pueblo de la amenaza de Dios, y que protejan a Dios de la amenaza de la impureza del pueblo. Ese ministerio será para los sacerdotes su privilegio y su fuente de subsistencia, de poder e incluso de lujo.

La determinación de las leyes y su .uplicación a la vida cotidiana fue una necesidad inherente al movimiento fariseo, que arrebató a los sacerdotes el monopolio de la pureza y de las leyes; peıo ahora serán los doctores de la ley, los escribas, los que se lo apropiarán; con ello se refuerza ideológicamente la estratificación social y la marginación del pueblo, incapaz de conocer y cumplir las minucias casuisticas a las que sólo tienen acceso los sabios. La pureza "defendida" por una ley multiplicada tan prolijamente, se hace inasequible a las mayorías y se convierte en privilegio de unos cuantos que, a base de méritos, se aseguran la bendición de Dios para sí. La gratuidad en la elección. origen de la fe de lsrael, queda relegada a segundo plano. Las obras de la ley son la garantia de la pertenencia al reino y a base de méritos se lo conquista y se lo presiona para que llegue. 


\section{2) El pueblo en tiempos de Jesús}

Pueblo abandonado. Sus guías espirituales no se preocupan de ellos; los sacerdotes viven en ese doble juego de complicidad con los romanos y defensa de sus propios intereses; los fariseos podrian ser sus guias, pero aun siendo del pueblo no lo aman, sino que incluso lo desprecian porque se sienten superiores a ellos; los escribas hacen inasequible el saber; los esenios se han agregado y evitan todo contacto con el pueblo.

Pueblo excluido. En el terreno ideológico la estratificación es aún más dolorosa, si cabe, que en lo económico-politico, por cuanto afecta al núcleo mismo de la identidad judia y su esperanza; la pertenencia al grupo de escogidos de Dios. Cada una de las diferentes escuelas o partidos pretende tener a Dios de su parte y excluye a los demás de manera más o menos radical. Con mayor o menor razón, por distintos conceptos los grupos dominantes excluyen al pueblo de la promesa. Predomina los fariseos en lo ideológico; la inflación de las leyes en torno a la fuerza trae un descuido práctico y atenuación de las exigencias de la ley de la alianza y una desvirtuación del mandato del amor, reducido a uno de tantos mandamientos. La preocupación por la pureza tiene la finalidad de evitar la profanación de la santidad de Dios, que parece vulnerable a la impureza humana y se defiende matando al que la profana. Esto trae consigo una dinámica de exclusión: hay que determinar legalmente las ocasiones de impureza y excluir al impuro; la mujer resultará discriminada por estar permanentemente afectada por la impureza (ciclo menstrual más siete dias de purificación, y de cuarenta a ochenta dias de purificación después del parto, según haya tenido un niño o una nifia). En la cumbre de esa pirámide excluyente está Dios, justificando la estratificación de una sociedad "santa." Dios será Dios de los perfectos, no de los disminuidos, que no podrán acercarse a él. De ahi también la relevancia de los sacrificios para aplacar a Dios, a quien se le llega a designar como "La plaga"' (Num. 17, 12-14), a quien se calma mediante holocaustos, "calmante aroma" que con nadie comparte. Este carácter "mortal" del culto y de la pureza explica la relevancia del sacerdocio y del templo: Dios queda localizado y encerrado en un lugar de protección, administrado por unos elegidos excluidos.

Pueblo expectante. La memoria histórica de la elección y la promesa se convierte en dolor al verlas incumplidas y al verse excluido de ellas por parte de los grupos dominantes. Las dominaciones políticas pasadas, las catástroles nacionales las ha sobrellevado como castigo a la infidelidad. Pero ahora no comprende qué pasa ni de quièn es la culpa. Los fariseos dicen que es del pueblo; lo mismo piensan los esenios; los saduceos dicen que no hay nada que esperar para el futuro, y que el presente (felicidad o infelicidad) ya muestra de parte de quienes está Dios y a quienes considera justos; los zelotas, en cambio, dicen que ya no es tiempo de pasividad ante un supuesto castigo, sino de resistencia contra el dominador. ¿Quién tiene razón?

Pueblo desorientado. Se debaten entre la desesperanza y la inquietud mesiánica, pero ante la división que enfrenta a los partidos dirigentes entre sí, y ante la chisis tan severa de toda esa época, que desembocará en la guerra judia y la 
destrucción de Jerusalén el año 70 , se agrupa en Iorno a quien le ofrezca alguna alternativa. Apoya a los zelotas, se guia por la doctrina farisea, aunque vacila entre las dos corrientes: la estricta de Shammay y la más laxa de Hillel; acude a los sacerdotes saduceos, va tras el Bautista, aclama a Jesús, pero, por haber introyectado dentro de si los criterios de los grupos dominantes, terminará por abandonarlo en manos de sus enemigos. Y ante los rumores crecientes de un fin ya próximo, se pregunta: ¿Es que no hay ninguna alternativa?

\section{Relaciones entre grupos de poder y pueblo}

Esıa "condición del pueblo," esta situación de despojo, exclusión y muerte, ha sido causada por factores externos al pueblo mismo, y es el resultado de la práctica de los grupos de poder respecto del pueblo, práctica que constituye, de hecho, un proyecto de dominación y desigualdad.

\section{a) Instancia política: Ia 'Pax romana'}

El año de la creación del mundo, cuando en el principio creó Dios el cielo y la tierra, cinco mil ciento noventa y nueve; del diluvio el año dos mil novecientos cincuenta y siete...; en la Olimpiada 194; de la fundación de Roma el año 752; del Imperio de Octaviano Augusto el 42; estando todo el Orbe en paz... Jesucristo... nace en Belén de Judá, de la Virgen María, hecho hombre (Martirologio romano).

Aparte de la ingenuidad histórica de los datos, este párrafo revela que nos hemos tragado la píldora. Hemos hecho nuestra la versión de los dominadores, cantada por poetas cortesanos ${ }^{29}$ sobre la nueva era "mesiánica," inslaurada por el emperador romano. Si ellos estaban en paz, entonces todo el orbe estaba en paz.

Prueba de esto son las siguientes opiniones que resumen el reinado de $\mathrm{He}$ rodes, ejercido en su mayor parte bajo el imperio de César Augusto:

El reinado de Herodes fue, en su mayor parte, un periodo de paz para $\mathrm{Pa}$ lestina tras los largos y penosos conflictos bélicos y las devastaciones de las guerras. Gracias a él participó el país en la Pax Augusta, la paz imperial de Octaviano Augusto. fo $^{\circ}$

Pero, en realidad, se debió menos a él que a los frutos de la pax romana conseguida por Augusto. Augusto se convirtió en el gran modelo de Herodes, que se dedicó especialmente a integrar en esta pax romana a la notoriamente agitada Judea, costara lo que cosfara. ${ }^{31}$

La Pax romana es casi un dogma histórico. Pero ¿no tenían ninguna justificación las actividades de agitación del pueblo judio? ¿Qué tanto llegó de la pax a los pueblos dominados? Eso es algo que no interesa para la versión oflcial de la historia.

César Augusto ha sacado lecciones de los fracasos de los gobernantes romanos anteriores, y a base de una astuta manipulación de la opinión pública 
mediante la cual llega a presentarse como indispensable, aparentemente conservará las instituciones republicanas así como las antiguas magistraturas, pero monopolizará las funciones necesarias que le aseguren de hecho el poder absoluto, en el terreno político, económico, militar y religioso. Para eso organizará todo el territorio conquistado, nombrando procónsules (para las provincias "pacificadas"), , legados personales bajo su autoridad directa en las provincias donde hay legiones establecidas, y prefectos o procuradores, dependientes del legado más próximo, para los territorios que presenten algún problema especial, (ese será el caso de Judea a partir del año 6 d.C.). Asi se forma una estructura de poder politico que no se mueve por una preocupación en lavor del pueblo, sino en función de sus propios intereses económicos y politicos; de su venalidad y corrupción nos dejó constancia Flavio Josefo en varias partes; $\mathrm{cf}$. por ejemplo Bell, II, 14, I, su actitud pro-romana (cf. Vita, 76) lo hacen poco sospechoso en este punto.

Dado el interés que tiene la zona para proteger sus posesiones de Asia Menor y Siria, la política romana será hasta cierto punto condescendiente con los principales judios, en cuyo favor promulgará una serie de decretos más conformes con la idiosincrasia judia: los exime del servicio militar porque en él tendrían que violar el sábado; les garantiza el culto en el templo y se encargará de velar para que los paganos no violen la prohibición de entrar en el lugar reservado a los judios; además pemitirá el cobro del tributo al templo. ${ }^{32}$

Elemento fundamental de la dominación romana son los altos impuestos que cobra de los pueblos conquistados. Judea debe aportar a las arcas imperiales, por concepto de dominación, 600 talentos anuales, cantidad cercana a las 26 toneladas de plata. ${ }^{33}$ Se cobra tributo por la tierra (tributum solt) y por las rentas moblliarias (tributum capitis); ${ }^{34}$ hay tasas sobre las ventas y de. rechos aduaneros, ${ }^{35}$ en torno a lo cual se teje una red de soborno. ${ }^{36}$

Para el cobro de los impuestos, Rome ha organizado una estructura sumamente eficaz. El encargado general del cobro es el procurador o el legado imperial; este, a su vez, hace responsables a los dekaprotoi, a quienes elige de entre los ancianos, haciéndolos garantes del pago, con sus propios bienes. ${ }^{37}$ En la sociedad judía no serán ellos quienes cobren directamente el tributo, sino los publicanos, organizados en sociedad para encargarse de esa tarea. ${ }^{38}$ A Roma le basta con que se le pague; no importa como lo logren los recaudadores. De hecho, este oficio, despreciable y aborrecido por el pueblo, que lo ve asociado con la explotación injusta del imperio romano, era fuente de enriquecimiento llegitimo para los publicanos, quienes podian alterar las tasas impositivas sin que nadle pudiera reclamarles (cf. Lc. 3,13); por eso los puestos de recaudación y aduanas eran muy codiciados. Otra odiosa fuente de enriquecimiento será la actividad cambiaria de moneda romana y judfa para el pago del diezmo y del tributo al templo.

Hay que notar que la actividad en torno a los impuestos tocaba las tres instancias de la sociedad judla: la económica (como fuente de enriquecimiento para Roma, la corte judla y los intermediarios, y de empobrecimiento y despojo para el pueblo), la politica (como reforzamiento del dominio y explotación 
del pueblo y como pretexto para la represión de parte del ejército, a la vez que será causa de descontento y levantamientos armados del pueblo, e incluso de la guerra judia), y la ideológica (por la labor de legitimación que tienen que realizar los sacerdotes para que el pueblo pague, a pesar de ser contra la fe de Israel respecto del dominio exclusivo de Yahvé; esto será motivo del alzamiento zelota). ${ }^{39}$

Particular importancia tiene en el aspecto político la corte herodiana. Judea sufre el despotismo de esa familia desde el 40 a.C. aproximadamente, hasta el 6 d.C. En Galilea seguirá hasta el 39 d.C. Nos han llegado elocuentes testimonios de su crueldad, su ambición y ostentación, que la llevan a confiscar los bienes de ricos judios, tras ejecutarlos, ${ }^{40}$ y a imponer tributos extraordinarios al pueblo. "Como gastaba más de lo que le permitían sus recursos, tenía que mostrarse duro con sus súbditos." 41

Dado el déficit de legitimidad que tiene por su origen idumeo, Herodes sólo podrá sostenerse "gracias a un gobierno de fuerza, que propagaba el terror y no retrocedia ante nada." 42 En realidad, la tal Pax romana fue, bajo Augusto y Herodes, la paz de la represión. Y sus beneficiarios, los poderosos tanto de Roma como de Palestina y no el pueblo. 43 "Los judíos tuvieron que pagar por "la paz y el orden" un precio bastante caro. Este consistió en un gobierno implacable y en una dureza extrema contra todos los adversarios, reales o supuestos. Lo único que contaba para Herodes era el poder; por él sacrificaba, sin dudarlo, todo lo demás." 44 Todos los miembros de la familia asmonea fueron asesinados, incluida su esposa Mariamne y sus hijos; hace matar también al Sanedrín el año 37 a.C. 45 Los impuestos que exprime del pueblo se calculan en más de 1.000 talentos ${ }^{46}$ equivalentes, según los cálculos anteriores ${ }^{47}$ a unas $\mathbf{4 0}$ toneladas de plata o al salario de $\mathbf{1 0}$ millones de dias de trabajo. Un ejército de mercenarios y un ejército de delatores "mantenían a raya a la indignada población judia y difundian una atmósfera de permanente recelo." 49

Intentará adquirir legitimidad presentándose como el nuevo David, al que incluso pretende superar, mediante la obra de reconstrucción del templo. "Así usurpó Herodes no sólo el poder, sino también las esperanzas mesiánicas de Israel." 49 Considera a Galilea "tierra del rey;" los grandes latifundios o son propiedad de la familia real o de sus colaboradores (a quienes los cede en recompensa de servicios prestados) o de ricos que los adquieren en compra, 50 contra el derecho de Yahvé.

Esa situación de represión estalla incontenible a su muerte en el 4 a.C.; las revueltas que surgen entonces son aplastadas sangrientemente en Judea por Quintilio Varo, legado de Siria; crucifica en las afueras de Jerusalén a 2.000 alzados (lestai o bandidos, según Roma). ${ }^{\text {si }}$ A ese pueblo estrujado hasta la sangre lo deja a su muerte empobrecido totalmente, con la moral resquebrajada e impasible a toda desgracia. ${ }^{92}$ Por ese tiempo, Jesús debe tener unos dos aflos de edad.

El reinado de Arquelao, su hijo, en Judea, sigulo la misme linea. Durante la pascua del afio 4 fueron muertos por sus soldados unos 3.000 hombres, según datos de Flavio Josefo. ${ }^{53}$ El descontento se manifestará en alzamientos 
populares, encabezados por un tal Atronges y sus cuatro hermanos, con éxito durante años. ${ }^{54}$ Las denuncias sobre su crueldad y venalidad llevarán a Roma a destituirlo el ano 6 d.C. Y es entonces, probablemente con motivo de la segunda fase del censo, puesta en marcha coincidentemente con el cambio de estructura política que supuso la destitución de Arquelao, cuando surge el movimiento zelota en Galilea, en franca oposición a la recaudación del impuesto. 55 Iniciado por Judas el Galileo en Séforis, tambièn ese alzamiento será ahogado en sangre. Los habitantes de Séforis serán vendidos como esclavos, en represalias. ${ }^{56}$ Esto sucede a unos 5 kilómetros de Nazareı, donde vive Jesús, quien por entonces cuenta probablemente con unos doce años. ${ }^{57}$ Los hijos de Judas, Simón y Jacobo, serán crucificados unos 40 años más tarde ${ }^{58}$ posiblemente junto con Teudas; 59 un tercer hijo suyo, Menahem, tomará parte en la guerra judía del 66 y será asesinado por sacerdotes, quienes ven en él un rival a su liderazgo. 60

La destitución de Arquelao trajo la necesidad de una reestructuración de la organización política. Un prefecto, dependiente del legado sirio, gobernará en nombre de Roma. Pilato obtendrá ese cargo, que ocupará del 26 al 36, por influencia de Sejano, de conocidas tendencias antijudias. ${ }^{61}$ A pesar del interés que tienen los romanos en ganarse a la clase alta, por el influjo que ejercen sobre el pueblo, y a pesar de que de hecho hubo una estrecha colaboracion entre Caifás y Pilato, 62 sin embargo, fue notoria su actitud provocadora y su crueldad, durante el desempeño de su cargo. "Corrupción, violencia, latrocinio, crueldad, exacción y frecuentes ejecuciones sin juicio" es la sintesis de su gobierno, según Filón, de Alejandria. ${ }^{63}$ Introdujo en el templo enseñas romanas, con la efigie del águila imperial; usurpó dinero del tesoro del templo para obras públicas; acunó monedas con la imagen del César; ${ }^{64}$ mató un grupo de galileos que se disponia a sacrificar sus corderos pascuales, mezclando su sangre con la de los sacrificios (Lc.13,1); ${ }^{65}$ y mandó crucificar a un galileo llamado Jesús.

También los soldados llegaron a actitudes de fanatismo antijudio, las cuales crearon fricciones innecesarias; se podria decir que la relación RomaJudea osciló entre la concesión y la represión. ${ }^{66} \mathrm{Y}$ la provocación romana llegará al máximo cuando Caligula intente poner su estatua dentro del mismo templo, alrededor del 40 d.C. El asesinato del emperador impedirá la rebelión abierta y el estallido del sentimiento anti-romano, reprimido por tanto tiempo.

Con Herodes Agripa I como rey de toda Judea la situación se distiende algo, pero a su muerte prematura (gobernó toda Judea soblo de los 41 a 44) la reconversión de Judea en provincia romana nuevamente hará surgir otra vez el conflicto, agudizado ahora por la gran carestla y hambre de los afios 40 , a lo cual se unirá la corrupción en la administración pública, por parte de los procuradores romanos. "La violencia represiva de las fuerzas de ocupación y la contraviolencia revolucionaria se caldearon mutuamente." 67 El asesinato de un peregrino galileo exigirá en el ano 51 el empleo de todas las fuerzas de combate del procurador Cumano. Roma tomara medidas contra los responsables de ese asesinato, pero ya no logrará pacificar la situación de rechazo generalizado contra Roma. La literatura epocallptica del tiempo de Herodes y del siglo 
I exacerbarán el sentimiento anti-romano y la esperanza del juicio sumario y definitivo de Dios contra los dominadores.

Los romanos no pueden comprender a esos "bandidos" y "ladrones" (lestai) judios, que no aceptan la Pax romana ofrecida a todo el mundo tan de buena voluntad. Tácito resumirá el estupor romano, que sintetiza el problema de los imperios de todos los tiempos: Augebat iras quod soli judaei non cessissent. ${ }^{68}$ Es algo que el imperio nunca aceptará de los pueblos pequefios: que no se dobleguen a sus presiones e intereses. La constante represión romana da constancia de su incapacidad de comprensión del motivo profundo que suscita la rebeldía, y por eso nunca intenta un camino más constructivo. ${ }^{69}$

El dominio político romano tambien incide en el sector ideológico: reasume el "derecho," usurpado anteriormente por Herodes, de imponer y deponer al sumo sacerdote, a quien también le retiene los ornamentos sagrados ${ }^{0}$ para prestárselos sólo durante la festividades. Valerio Graco, procurador anterior a Pilato, depondrá a Anás (15 d.C.) y pondráa a Caifás, quien durará del 15 al 36.71 Mediante esa dependencia tan estrecha del mecanismo de la concesión arbitraria dominará al sanedrín; igual sucederá por las concesiones hechas a los demás miembros, convertidos en terratenientes por obra y gracia del imperio romano. ${ }^{72} \mathrm{El}$ sanedrín pondrá su autoridad moral de parte del imperio en la represión de los movimientos mesiánicos de resistencia. Un caso particular fue el de un galileo llamado Jesús: en su asesinato fue decisiva la trama de intrigas con la cual lo desautorizaron ante el pueblo los sacerdotes y los ancianos, y la colaboración que prestaron a los romanos denunciándolo como sospechoso de pretender cambiar la situación.

La Pax romana: la trampa para la vida de un pueblo. "En equel periodo de poco más de un siglo perdieron la vida unos doscientos mil judios... y eso es aún más terrible si recordamos que los que murieron en la guerra eran lo más selecto flsicamente de la nación, y los que habian sido asesinados por Herodes, lo más selecto intelectual y culturalmente."73

\section{b) Instancla económlca}

Cuando tratamos de la dominación romana hicimos referencia al aspecto económico porque lo consideramos un elemento fundamental por el cual se expresa y refuerza dicha dominación. Recordemos algunos datos que nos dejan claro quienes son los beneficiarios y quienes los perjudicados en el terreno económico. Sólo Judea page 600 talentos anuales a Roma; los ingresos de Herodes por impuestos son de alrededor de 1.000 talentos. Las actividades que posibilitan esa dinámica despojo-acumulación son las siguientes: la expropiación de la tierra por parte de los romanos, la concesión en favor de los privilegiados judlos (corte galilea, terratenientes judios), la actividad tributaria, que beneficiaba directamente a Roma y a la corte e indirectamente a los intermediarios (recaudadores y cambistas) ${ }^{1 / 4}$ así como a otros funcionarios romanos: la actividad económica en torno a la religión (diezmos, limosnas, sacrificios) lo cual beneficiaba indirectamente a los sacerdotes, a los comerciantes y a los traficantes, e indirectamente, a los habitantes de Jerusalén, y las activida- 
des de construcción y comercio, que aportaban fuentes de trabajo para los jerosolimitanos.

La provincia vive más de los contrastes entre los ricos terratenientes, ausentes de sus tierras, y los pobres que viven de trabajos esporádicos; hay un número indeterminado de pequeños terratenientes quienes viven de sus tierras, y luay tambièn lo que se podria llamar trabajadores independientes: en Galilea, en el margen del lago, algunos de los pescadores, quienes tienen asalariados que trabajan con ellos; en las ciudades y pueblos, los artesanos, atenidos al tra. bajo que les va siendo solicitado cada día.

Particular importancia tiene para el tema de este estudio la actividad económica que se realiza en Jerusalén y en corno al templo. Las concesiones romanas a los ancianos sobre la tierra y a las familias sacerdotales sobre el ejercicio dei culto y el cobro del impuesto religioso permiten que haya quienes viven con verdadero lujo y despilfarro. ${ }^{75}$

Toda la economia está centrada en torno al templo. ${ }^{76}$ Los sacrificios requieren una gran cantidad de victimas, sobre todo en tiempos de pascua. Hay todo un comercio organizado en torno a ello, el cual beneficia directamente al sumo sacerdote y a las principales familias; ${ }^{77}$ de los sumos sacerdotes dependen las licencias para la instalación de puestos en el templo; ${ }^{78}$ y los cargos en torno al comercio, gobierno y tesoro del templo se conceden a miembros de la misma familia. 79

Las fiestas religiosas son un momento especial que propicia la acumulación de capital en Jerusalén: una exégesis rigurosa de Num. 18, 20-23 y Lev. $27,30-31,80$ textos de la tradición $\mathrm{P}$, da origen a la práctica de los dos diezmos, uno de los cuales debe ser entregado al templo, ${ }^{81}$ y el otro gastado en Jerusalén. ${ }^{82} \mathrm{El}$ hospedaje de los peregrinos tambien representa una fuente de entradas económicas para los habitantes de Jerusalén; aunque no se podla cobrar por el hospedaje, sino que se debía of recer gratuitamente, era costumbre compensar a los hospedadores con las pieles de las victimas sacrificadas; hasta tal punto se hizo derecho esta costumbre que incluso se llegó al caso de que las arrebataran por fuerza a los renuentes. ${ }^{83}$ El costo de una piel la calcula Jeremlas en unos 16 a 20 denarios; 84 y aunque no sea posible el cálculo del número de victimas sacrificadas, porque no son fiables los datos de Flavio Josefo a este respecto, ${ }^{85}$ Jeremias considera que "es seguro que se trataba de decenas de miles" durante la pascua. 86

El templo era la mayor fuente de trabajo de toda Palestina. Se habla de 7.200 sacerdotes, más 9.600 levitas ${ }^{87}$ y de unos 18.000 trabajadores en la construcción del templo, que aún se continúa en tiempos de Jesús. ${ }^{88}$ Naturalmente esta situación de privilegio, más las exenciones de impuesto concedidas por Roma a Jerusalén, hacian de sus habitantes gentes poco dispuesta a secundar un cambio de situación o una lucha contra los romanos. ${ }^{89}$

Un fenomeno típico de Jerusalen, como ciudad que tiene que ser proveida desde fuera para todes estas actividades, incluso para la alimentación, es la inflación de los precios. Las actividades de transporte e intermediarios reper- 
cuten en los precios, los cuales llegan a ser entre 3 y 6 veces más altos que en el campo; ${ }^{90}$ y las leyes del mercado (oferta-demanda) afectan también al comercio de victimas para los sacrificios. Jeremias trae un caso muy significativo, narrado por la Misná: ${ }^{91}$ alrededor de los años 60 d.C. se habia encarecido tanto el comercio sacrificial que dos palomas, (el sacrificio de los pobres) llegaron a venderse en dos denarios oro. Si éste se calcula a 25 denarios plata, ${ }^{92}$ y éste equivale a un dia de trabajo, ${ }^{93}$ un sacrificio como el que ofrecieron por Jesús sus padres habria costado lo equivalente al salario de 50 días de trabajo. De paso hay que notar lo inalcanzable de la pureza para los pobres.

Esta inflación se agudizará, naturalmente, en tiempos de calamidades. Los precios entonces llegarán a subir hasta un 1.600 por ciento. ${ }^{94}$ Los artículos de lujo son inalcanzables para la gente del pueblo; el perfume con el que una mujer unge los pies de Jesús (Mc. 14, 3-9) habria costado lo equivalente al salario de $\mathbf{3 0 0}$ dias de trabajo. Los compromisos matrimoniales con personas de Jerusalén suponían para los de fuera un desembolso sumamente fuerte, señal del alto interes que habría en emparentar con "los de la capital." 95

Pero ese centro judio lo es también de la mendicidad 96 y de la desocupación, agravadas por los numerosos casos de lisiados e impedidos que viven de la caridad pública en, torno al templo. Jeremias sintetiza de esta manera la peculiaridad de Jerusalén en lo económico: importantes grupos de la población viven de la caridad; hay también una tensión social surgida entre esos estratos pobres, por una parte, y la corte y nobleza sacerdotal, por otra; la ciudad debe su prosperidad a la importancia religiosa. ${ }^{97}$

\section{c) Instancla Jdeológica}

El panorama de las relaciones entre los grupos de poder ideológico y el pueblo no es nada sencillo. Es un momento de fuerte crisis. Diferencias importantes en el tenor de vida y en la manera de concebir el designio de Dios sobre el pueblo, la pertenencia al núcleo de destinatarios de las promesas, asi como la forma de entender la ley, las tradiciones y las expectativas mesiánicas, configurarán cuatro tendencias principales en torno a las cuales se organizarán grupos bien diferenciados en su identidad y en su práctica. Bien se podria hablar de una especie de partidos religioso-politicos que, en base a esas diferencias, se combatían con vehemencia. ${ }^{98} \mathrm{Su}$ origen más inmediato puede remontarse al importante hecho que marcó el último periodo de la historia de Israel previo a la dominación romana: el alzamiento macabeo y el dominio de la dinastia asmonea, que fue su heredera. Una breve referencia histórica servirá para enmarcar el panorama ideológico.

En la resistencia contra Antloco Eplfanes hubo dos corrientes: una desinteresada por la política, centrada en el culto y en la expectación de una intervención de Dios; otra, orientada al apoyo activo de la lucha armada por la libertad del pueblo. De esta corriente nacerá el movimiento macabeo en el cual más tarde se inpirarán los zelotas; la primera cristaliza en lo que se llamó el movimiento asideo (o de los piadosos). Tras la victoria de Judas Macabeo y el pacto de libertad religiosa que pone el sacerdocio en manos de un legítimo des- 
cendiente sadoquita, Alcimo, los asideos se dan por satisfechos. Los macabeos, en cambio, seguirá luchando hasta conseguir la independencia politica completa. Una vez conseguido el poder, los sucesores macabeos comienzan a acaparar incluso la función sacerdotal; Jonatán rompe la línea dinástica sadoquita al ser investido sacerdote en el 152 a.C.

Ese hecho provocará dos posiciones dentro del movimiento asideo, que lo llevarán a la división y separación del ala radical, los esenios, que defienden la pureza dináslica sadoquita y rechazan como impuro el templo y el culto en manos de los sacerdotes asmoneos; bajo la dirección del maestro de justicia se refugiarán en el desierto en comunidades aisladas, donde esperan la venganza de Dios contra los impuros en la batalla escatológica que los constituirá a ellos en el resto definitivo de Israel. La otra posición será la de los fariseos. Están en desacuerdo con los sacerdotes por su politica helenizante, pero no se separan del templo ni del culto. Pero durante el reinado de Alejandro Janeo serán perseguidos por la corte, y varios de sus miembros serán crucificados por su oposición al régimen. También han sido atacados por los esenios, quienes les reprochan no haberlos seguido en su postura radical contra Jonatán. ${ }^{99}$ Después de eso irán cobrando cada vez más ascendiente tanto sobre el grupo de poder como sobre el pueblo, hasta llegar al tiempo de Jesús cuando mantenian un poder ideológico predominante, como veremos. Los saduceos, pertenecientes a la dinastia sacerdotal hecha a un lado, tendrán una actitud acomodaticia y seguirán en el templo; también su posición de poder se fortalecerá, gracias a esa actitud, salvo en un momento en tiempos de Herodes, quien los ve como adversarios por su riqueza y su acceso al sacerdocio, que a él le está vedado por su ascendencia semipagana.

Después de esta rápida situación en el origen de estos movimientos, veamos algunas de las características, para entender la lucha que los enfrentará entre sí, y la práctica que realizan respecto del pueblo.

\section{1) Los fariseos}

Comenzamos por ellos, el grupo más influyente desde el punto de vista ideológico. 100 Desde su origen están marcados por la oposición al grupo saduceo. Como camino para la formación del verdadero Israel hicieron extensivas a los miembros de la comunidad laica, y para la vida cotidiana, las normas de pureza sacerdotal de la Torah; los saduceos ven le pureza sacerdotal como distintiva diferenciante de su casta y así la quieren conservar, aunque reducida a los espacios y tiempos cultuales, y no ampliada a todos los ámbitos de la vida cotidiana. Ya en otros momentos habia surgido en Israel el conflicto entre lo que podría llamarse "sacerdocio laical" y "sacerdocio ministerial."

También habrá oposición entre fariseos y saduceos por la concepción materialista intramundana que éstos últimos tienen de la vida, por lo que no esperan ni un cambio en la situación, ni el reino de Dios, ni la resurrección de los muertos, razones por las cuales se "permiten" una vida laxa desde el punto de vista de las observancias de pureza ritual. Finalmente, el que los fariseos den a 
la Torah el papel central por encima del templo mismo ${ }^{101}$ los distanciará también de los sacerdotes saduceos.

Se trata, pues, de un movimiento laical con aspectos de oposición o critica a lo sacerdotal. Pero no se podria afirmar, como lo hace J. Jeremias, que sean el partido del pueblo. ${ }^{102}$ Es indudable el prestigio que tienen entre la gente, sobre todo por su vida austera y su coherencia personal, en contraste con la vida de lujo de la aristocracia sacerdotal; también por sus conocimientos sobre la ley. Pero no son los fariseos un movimiento universalista, que abra las puertas al pueblo sencillo, que les of rezca una alternativa de salvación; todo lo contrario. La entrada a sus comunidades pasa por estrictas pruebas y reglas de admisión, en las que se concreta su concepción de la santidad de Dios como separación y distancia. ${ }^{103}$ El "mandato" sobre la santidad lo entienden asi: "Sed santos (qedosim), es decir, separados" (perusim = phariseos). "Como yo soy parus asi ustedes deben ser perusim." 104 De esta manera convierten a Dios en el primer gran fariseo.

Pero esa exclusividad tiene como correlato la exclusión. Los fariseos excluyen a todos aquellos que no observan las prescripciones de la Torah tal como la entienden sus escribas y doctores, responsables de la interpretación y adaptación de la ley a la vida ordinaria ${ }^{105}$ y que con el fin de proteger la ley de posibles quebramientos o violaciones han organizado un conjunto de 613 mandamientos, divididos en 248 prescripciones y 365 prohibiciones; 106 uno de entre todos ellos es el mandamiento del amor. ${ }^{107} \mathrm{La}$ insistencia más fuerte estará en tres puntos: la observancia del sábado, ${ }^{108}$ la guarda de la pureza ritual y el pago de los diezmos. Cumplir con esto entraña para el pueblo la dificultad, por un lado, del desconocimiento de tanta minucia y, por otro, de la angustiosa situación económica en que vive.

Es precisamente ese minucioso afán de fidelidad el que hace inasequible para el pueblo el cumplimiento de la ley, dado que le es imposible el acceso a ese mundo privilegiado de los escribas, que basa su poder en el saber. Ese saber es lo que cierra al pueblo el paso al reino de Dios (Mt. 23,13) abrumándolo con cargas insoportables (Lc. 11,46).

Y en ellos creará una autosuficiencia por la cual se consideran justificados por méritos propios, que ni Dios mismo puede poner en cuestión, obligado como está a tener misericordia con el justo, 109 a quien allana el camino y no destruye en la represión. 110 De eso nacerá el desprecio que sienten por el pueblo "injusto," es decir, sin meritos que los protejan; contra ese pueblo se mostrarán duros y orgullosos. Considerándose a sl mismos el verdadero Israel, mostrarán su hostilidad contra quienes no tienen una observancia como la de ellos, ${ }^{111}$ y en la vida cotidiana llegarán incluso a ejercer un boicot económico y social contra el pueblo. ${ }^{112}$ En esa actitud excluyente expresan el rechazo irremediable que el mismo Dios hace del pueblo: "el castigo soblo ha venido al mundo por culpa de los am-ha-ares;" 113 "los am-ha-ares no resucitan." 114

Con mayor razón rechazarán a los paganos y a los pecadores. La misericordia de Dios no se dirige al pecador, sino al justo; y cada uno vale lo que valen sus obras. La superioridad de los fariseos sobre los paganos se basa en que 
poseen la Torah; esa superioridad, junto con la fidelidad a la realeza davidica hace impensable cualquier colaboración ni reconocimiento del imperio que ocupa Israel contra la voluntad de Dios. Pero son hostiles a la resistencia violenta, y esperan que sea la observancia de la ley lo que empuje a Dios a enviar a su mesías. La observancia tiene, pues, importancia escatológica: "grande es la justicia ( = hacer obras meritorias) que hace aproximarse la salvación;" "115 "si los israelitas hubieran sólo observado dos sábados de acuerdo con sus preceptos, quedarian salvados."116

Esta actitud los hará chocar con los grupos de resistencia activa; a diferencia de ellos no creen que la venida del reino pueda acelerarse mediante un activismo politico. Será obra inmediata de Dios, y consistirá en el castigo de las naciones paganas y la restauración nacionalista del verdadero Israel, que son ellos. De esa venganza contra las naciones queda constancia en los Salmos de Salomón (17 y 18) y en el Testamento de Moisés $(10,1-10)$, ambos de inspiración farisea. 117 .

\section{2) Los saduceos}

No es improbable que su origen pudiera remontarse hasta el profeta Ezequiel, como anota Winter; ${ }^{1 / 8}$ Ezequiel da primacia a la familia sadoquita sobre el sacerdocio levítico (Ez. 44, 10-45,6). Pero el término "saduceo" como denominación de un partido habria que situarlo hacia mediados del S. II. a.C., según una tradición rabinica. ${ }^{119}$ Cuando la dinastía asmonea asoció la función sacerdotal al poder politico, asumiendo la dignidad del sumo sacerdocio, se provocó una escisión en el seno de los sacerdotes: un grupo formará el movimiento separatista esenio en torno al maestro de justicia, (sacerdote sadoquita) y otro grupo, también de sacerdotes sadoquitas, se aliará con el sacerdocio en el poder, y gracias a esa actitud acomodaticia conservarán sus privilegios en el templo. Esa actitud de astucia conservadora que marca sus orígenes, marcará también toda su historia. ${ }^{120}$

Inicialmente el movimiento sacerdotal, se abrirá también a la nobleza laica; asi agrupará en su seno a todos los privilegiados (poder económico, político y cultural), pero eso mismo es lo que los distanciará del pueblo: "no convencian más que a los ricos y no eran seguidos por el pueblo,"121 "su doctrina no es aceptada más que por un pequeño número, a pesar de ser los primeros en dignidad." 122

Son la fuerza sustentadora del poder del templo judio, y a su vez en él sustentan su privilegio. ${ }^{123}$ Todo esto configura un tercer rasgo de la mentalidad saducea: la mezcla de ideología conservadora (interpretación literal de la Torah) y de costumbres liberales (por influencias helenisticas). ${ }^{124}$

Su teologia conservadora los llevará a una intransigencia en la defensa de la letra de la ley, que no deja ningún resquicio para la misericordia, 125 y también a negar cualquier valor a las tradiciones orales de los fariseos. ${ }^{126}$ Esta será una de las fuentes de conflicto con ellos. Y ese mismo conservadurismo jdeológico-social, como también su concepción materialista de la salvación 
(derivada del Pentateuco, que pone un fuerte énfasis en la bendición material: posesión de la tierra, poder politico y económico para Israel) los llevará a rechazar toda expectativa apocaliptica por un reino fuluro, por un mesias, por la resurrección de los muertos, cosas que, según ellos, no pertenecen al núcleo de la fe judia, (incerpretada de manera fundamentalista).

Los saduceos son un claro ejemplo de cómo el lugar social condiciona la teología que se elabora. ${ }^{127}$ Lo que en el fondo están defendiendo es su propio status; la interpretación de la Escritura se convierte en un círculo vicioso de defensa ideológica del poder: "dado que todo (es decir, ellos) está bien, no hay que cambiar nada. Las promesas se han cumplido para Israel (= ellos); gozan de la posesión de la tierra prometida, de prosperidad material, que es la bendición de Dios, y el culto hasta para mantener esa situación de bendición; cualquier pretensión mesiánica lo pondria en peligro todo (es decir, su situación de privilegio), pues haria reaccionar a los romanos contra el pueblo (es decir, contra ellos)." 128 Interpretan el bienestar de que gozan como la sanción religiosa aprobatoria de Dios a su situación de privilegio como verdadero Israel. ${ }^{129}$

Y obviamente lo que más rechazarán es el movimiento revolucionario zelota y todo lo que se le asemeje. 130 "Sólo ya por consideración de sus propiedades son amantes de la paz;" $|3|$ aliados naturales de la romana, -como toda aristocracia nacional lo es de las fuerzas de dominación extranjeras - y colaboradores suyos en la tarea de control ideológico y de desmovilización del pueblo 132 ven con pánico cualquier posible alteración del orden y reaccionan ante ello con violencia (cf. Jn. 11, 47-48).

Especial importancia tienen entre los saduceos las familias de la aristocracia sacerdotal. Cuatro son las principales, que entre los años 37 a.C. y 70 d.C. acaparan 25 veces el sumo sacerdocio, (de los 28 ejercicios que hubo): la familia de Anás, 8; la de Boetos, 8; la de Phiabi, 3 y 3 también la de Kamith. 133 Siendo de por si el sacerdocio un núcleo cerrado que practicaba la endogamia para garantizar la pureza ritual en el matrimonio / $^{134}$ el sentido de casta se refuerza por el hecho de que se van alternando en el ejercicio del sacerdocio.

El perder el ministerio, (sobre todo si han sido destituidos) connotaba una descalificación por parte de los romanos; sin embargo, los sacerdotes cesados mantienen un cierto influjo (cf. Jn. 18, 12-14). Esto desencadena un mecanismo de ambición de poder para el que lo que menos cuenta es el carácter indeleble de santidad del sacerdocio; ${ }^{135}$ la búsqueda de perpetuación hará brotar grandes rivalidades entre las familias sacerdotales, que harán del sumo sacerdocio un juguete de las intrigas politicas: sobornos a los romanos, venalidades, abusos, ${ }^{136}$ mala formación teológica, transgresiones a leyes de pureza... Aquí está la principal fuente de conflicto que los enfrenta a los fariseos y que los hace perder credibilidad ante el pueblo, ${ }^{137}$ que se queja amargamente de ellos: "pues son sumos sacerdotes, sus hijos, tesoreros, sus yernos, guardianes del templo, y sus criados golpean al pueblo con bastones." 138

Ya en tiempos de Jesús era claro el proceso de decadencia del sacerdocio y todo este mundo de intrigas por el que se va degenerando. ${ }^{139} \mathrm{Sin}$ embargo, su 
papel ideológico sigue siendo necesario al pueblo: en una religión tan estratificante y excluyente como la judia, en la cual existían los diez círculos de santidad (que eran círculos que marcaban las diferencias y las distancias exis(entes en su seno), ${ }^{140}$ y en la cual se seguia manteniendo la idea de un Dios cuyo acceso era mortal al hombre del pueblo, y estaba permitido tan sólo al sumo sacerdote una vez al año, (y con muchas condiciones de pureza), la figura del sacerdote seguirá manteniendo un lugar de privilegio basado en esa función; ${ }^{141}$ su misma muerte se verá como expiatoria en favor de la comunidad. ${ }^{142}$

\section{3) Los zelotas}

La presentación sectaria de Josefo, quien quiere hacer de ellos unos bandidos, sembradores de todas las desgracias del pueblo, choca con la realidad profundamente religiosa de su verdadera motivación. ${ }^{143} \mathrm{El}$ punto central de su ideología es la interpretación que dan al primer mandamiento: el reino de Dios es incompatible con cualquier otra dominación sobre Israel. Durante siglos se ha aceptado como permitido por Dios, como prueba o castigo, el vivir bajo dominaciones extranjeras. Los zelotas, como antes los macabeos, rompen con esta situación. ${ }^{144}$

Sobre esta concepción religiosa se crea toda una ideología, que inicialmente es muy eficaz, que propugna la lucha escatológica por la liberación. Dos son los quicios sobre los que gira: la ardiente espera del reino de Dios y el celo fanático por la ley. ${ }^{145}$ Entienden la conversión como un cambio hacia la resistencia hostil y combativa, hacia la desobediencia a los poderes politicos, asumiendo con gran fortaleza el riesgo incluso del martirio, vivido como un acto de confesión de la grandeza de Dios, $y$ al cual atribuyen un valor expiatorio por los pecados de Israel. ${ }^{146}$

La resistencia encuentra eco en el pueblo al propugnar la lucha contra el pago de los impuestos. Pero no lo hacen por motivos demagógicos, sino por coherencia religiosa. Si Dios ha hecho donación de la tierra a lsrael, de manera inalienable e intransferible, el pago de tributo por la propiedad y usufructo de las tierras seria complicidad con la pretensión impia de Roma sobre la propiedad de la tierra de Dios por derecho de conquista, que usurpa el derecho único de Dios sobre ella. Además el crecido importe del cobro y la dureza de la recaudación propiciarán la colaboración del pueblo con ellos.

Otro elemento igualmente importante es la lucha contra el culto al emperador; sensibles desde siempre a ese tipo de pretensiones, el rechazo judio se focaliza especialmente contra la veneración de imágenes del emperador. Y las monedas tienen su imagen... Usarlas tiene una connotación de reconocimiento de su poder. ${ }^{148}$ La agudización de la conciencia de fidelidad al primer mandamiento ("no tendrán más Dios que a mi") exige la liberación de todo dominio; el pago de impuestos al César debía aparecer como idolatria y apostasía. ${ }^{149}$

Y como se oponian a la propiedad de la tierra por Roma, también se opondrán al acaparamiento que los colaboracionistas judios han hecho a costa 
del pueblo. La justicia social es elemento constituyente de su lucha: eliminación de los cobradores de impuestos, supresión de la usura, destrucción de los archivos de deudas, eliminación de latifundios y redistribución de la propiedad, y emancipación de los esclavos. 150

Dentro de la mentalidad zelota han penetrado algunas ideas esenias referentes a la guerra santa escatológica, que ellos traducen en términos militares. La llegada de Dios no hay que esperarla pasivamente, sino que depende de la acción revolucionaria que colabore activamente con Dios. Hay en ello toda una dimensión teológica que asume la colaboración del hombre con Dios, en contra del determinismo esenio o de la despreocupación de Dios ante la libertad del hombre, que caracteriza a los saduceos.151 Su finalidad es lograr la independencia politica y religiosa que permita a Israel ocupar su papel central en medio de las naciones, y el culto en un templo dignificado y purificado de los abusos de los sacerdotes saduceos. Prevalece en ellos la antigua esperanza politica y nacionalista sobre el futuro de Israel, que apela directamente a la sensibilidad popular, sobre todo en este momento en que los sentimientos están exacerbados por la presión de la dominación extranjera, las dificultades sociales y económicas, la reacción contra el incumplimiento de las antiguas costumbres y el ultraje al sentimiento religioso, perpetrado por helenistas y extranjeros. ${ }^{152}$ Del mesias esperan que restaure a Israel como pueblo y le devuelva su pasada gloria. El reino de Dios lo imaginan como un poder terreno y realista, identificado con el dominio del pueblo de Dios y ligado al ideal de la libertad política. 153

Condición fundamental para el cumplimiento de ese ideal nacionalista es la destrucción de la potencia pagana que mantiene sojuzgado al pueblo. El mesias encabezará la acción guerrera que destruya definitivamente a Roma y expulse a los sobrevivientes fuera de Israel, donde no podrán vivir en adelante, por ser impuros. Después de eso llegarán las bendiciones mesiánicas. ${ }^{154}$

Estas ideas influyeron particularmente en los jóvenes y en la población empobrecida del campo. Los habitantes de Galilea, Idumea y Perea son los más inclinados a la rebelión; en cambio la población urbana de Jerusalén y de las dos principales ciudades galileas, Tiberiades y Séforis ${ }^{155}$ rechazaban el movimiento revolucionario y se guiaban por las consignas de la aristocracia saducea. 156

El movimiento, sin embargo, caminaba hacia su autodestrucción, por causa de las disensiones ideológicas existentes entre sus jefes. "Tan pronto como consiguieron su objetivo e involucraron a todo su pueblo judio en la guerra con Roma, se rompió la unidad de acción revolucionaria. Cuatro, e incluso cinco distintos grupos de rebeldes se devoraron muruamente, en diversos frentes, dirigidos por sus ambiciosos jefes, en una sangrienta lucha por la correcta ideologia y la posesión del poder, hasta que el ejército de Tito apareció ante las puerıs de Jerusalén." 157 


\section{4) Los esenios}

Durante la dominación seléucida se da una helenización en los grupos dominantes judios, concretamente en la aristocracia sacerdotal; ${ }^{158}$ contra ello surge el movimiento de los hasidim (asideos o piadosos). Y la persecución que Antíoco Epifanes desata contra los judios observantes (167 a.C.) provoca una doble resistencia: la activa, de los macabeos, y la pasiva, de los asideos. El sufrimiento que conlleva la injusta persecución hace acuciante la pregunta sobre la justicia de Yahvé, y entonces la escatologia se convierte en apocaliptica, al transformarse el dualismo cosmológico en dualismo metafísico: los acontecimientos terrenos son el escenario de la lucha de los poderes supraterrenos: Dios y los ángeles, por un lado, y Satán y los demonios, por el otro. Los profetas vieron los acontecimientos adversos como un juicio de Yahvé por el que pretende educar a su pueblo y corregirlo; los apocalipticos hablan de acontecimientos tras los que vendrá el juicio de Dios, no para educar, sino para pronunciar la última palabra de salvación o de condenación. 159 La situación presente se ve como dominada por el mal y se espera el eón futuro como ruina del presente y liberación de los justos.

Eso se concretará en el libro de Daniel y en el Apocalipsis de Henoc, aproximadamente del mismo tiempo (mediados del S. II a.C.); el primero espera la liberación de parte de Dios, para establecer su reinado y dejando en segundo término el aspecto político directo, y el segundo con una orientación marcada hacia el nacionalismo activo religioso-militar y una escatologia terrestre que se logrará mediante la guerra santa. ${ }^{160}$ Influidos por el pensamiento oriental tratarán de calcular el momento de esa intervención. ${ }^{161}$

La resistencia armada de los macabeos consigue pronto la paz religiosa; los asideos se dan por satisfechos con eso, pero los macabeos seguirán en pie de lucha hasta conseguir la independencia y la refundación del Estado judio bajo el mando de la dinastía asmonea, sus sucesores. Todo marcha bien hasta el momento en que Jonatán asume para si el sacerdocio, que no le correspondia por no pertenecer a la familia de Sadoq. Como hemos visto al iralar de los fariseos, es entonces cuando se da la división al seno de los asideos: los perusim (fariseos) y los esenios (nombre derivado probablemente de la raiz esa $=$ consejo, es decir, hombres del consejo de Dios). ${ }^{162}$

Bajo la dirección del maestro de justicia esperan en el desierto la acción de Dios contra los que manchan el sacerdocio de Jerusalén; al pasar el tiempo comenzarán a edificar Qumrán (hacia el 130 a.C.). Un terremoto e incendios desıruyen los edificios, los cuales vuelven a reedificar el 4 a.C.; su destrucción final será el 68 d.C. durante la guerra judia.

Se llaman a si mismos los "convertidos de Israel"163 e "hijos de la complacencia de Dios,"164 y se consideran el único verdadero y santo Israel, 165 es decir, el "resto." Nacidos de una resistencia contra la impureza darán importancia fundamental a los lavatorios y baños rituales, ${ }^{166}$ así como al cumplimiento riguroso de los preceptos de pureza sacerdotal para toda la comunidad, incluidos los laicos. ${ }^{167}$ 
El sábado será objeto de preocupaciones especiales entre ellos, hasta el punto de tener un calenclario especial para que la importancia del sábado no se viera disminuida por ninguna fiesta; eso les llevará a problemas con los fariseos. "La división en trescientos cincuenta y cuatro dias permitia empezar siempre el año en miércoles, el dia de la creación del sol según Gen. 1, 14-19, cayendo los dias festivos en miércoles, viernes o domingo, pero nunca en sábado." 168

Dentro de Qumrán se vive en celibato y de manera monástica; fuera, en licndas, los laicos casados a quienes parece que se permiten las relaciones sexuales sólo en visıa a la procreación. ${ }^{169}$ Trabajan en cooperativa para enfrentar en común los problemas de subsistencia, y no tienen una economía privada, sino que lodo lo ponen en común para las necesidades de todos; reducidas al mínimo las necesidades materiales por la austeridad en que viven, dedican gran parte del tiempo al estudio de la ley; sin embargo, el punto de la propiedad privada parece haber sido motivo de diferencias dentro de la comunidad, al menos por lo que puede deducirse de las diferencias entre la regla de Qumrá y el Documento de Damasco. ${ }^{170}$

Se trata de una comunidad jerárquica, clasista y sacerdotal en la que los sacerdotes de Aarón tienen preminencia sobre los hijos de Israel. ${ }^{171}$ La comunidad debe ser "un lugar del Santisimo para Aarón... y una casa de perfección $y$ de verdad en Israel para establecer la alianza de acuerdo con las leyes eternas." 172 El templo es impuro para ellos, el establecimiento de un sacerdote no sadoquita ha quebrantado la alianza y los sacrificios han perdido su vigor. "Por ello se aparta la comunidad del culto del sacrificio y se crea para si misma, con su modo de vida y el servicio de Dios, sacrificios y expiación." 173

Con esa conciencia de ser el pueblo de los santos de la alianza, se convierten en un grupo elitista y cerrado que excluye y segrega a los demás. "Mientras que en el antiguo Israel el pueblo entero era el pueblo de la Alianza de Yahvé, aqui se ha transformado el pueblo de la alianza en una comunidad organizada que erige su concepción de la alianza en una ley de separación dentro del pueblo. En consecuencia, deben segregarse "lodos los que no son contados en tu alianza" ( $\mathrm{QS}$ V, 20)."174 No sólo eso, sino que el mandato de la separación de los exiraños se "completa" con el del odio a los enemigos. El juramento de entrada en la comunidad incluye el "separarse de todos los hombres perdidos, que caminan por el camino del ateismo." 175 Se prohibe el trato comercial y ordinario con quienes no pertenecen a Qumrá, incluido el compartir la mesa con ellos, así como el aceptarles regalos. ${ }^{\text {I76 }}$ Quien ha sido aceptado en la comunidad está obligado a "amar a todos los hijos de la luz, a cada cual según su suerle en la comunidad de Dios (o sea, según su jerarquia) y a odiar a rodos los hijos de las tinieblas, a cada cual según su culpa en la venganza de Dios," 177 que ellos son los encargados de determinar.

Esperan que el final traiga el perfeccionamiento de las instituciones judias; para ello vendrán un profeta y dos mesias, uno sacerdotal (de Aarón) y otro político (de Israel), inferior al primero; no se menciona para nada la descendencia davidica del mesías de Israel ni su dignidad real. En el Documento 
de Damasco aparece una organización de caracteristicas guerreras con la perspectiva de la guerra santa que pondrá el fin a la impiedad; ${ }^{178}$ la regla de la guerra habla de la batalla contra los kittim (los romanos que personifican los ejércitos de Belial); esa guerra es concebida como escatológica; recordemos que de hecho los esenios participaron en la guerra judia contra el imperio romano, movidos por todos estos escritos apocalipticos. ${ }^{179}$ La vida futura después de la victoria se centrará en Jerusalén y en su templo ya purificado de los impios sacerdoles no sadoquitas. ${ }^{180}$

Pero se les plantea pronto el problema de la demora del fin. No dudan, sin embargo, de que "lodos los periodos de tiempo vendrán por su orden, tal como él los ha establecido en los arcanos de su inteligencia." progresivo empeoramiento de la humanidad; al fin le antecederá la guerra de venganza, que durará cuarenta años; catástrofes cósmicas preceden al fin; ${ }^{182}$ luego vendrá el castigo de los malos, conducidos por los demonios a multitud de aflicciones, a la aniquilación eterna por la furia vengadora de Dios, al espanto continuo y al oprobio de la aniquilación en el fuego de las tinieblas; ${ }^{183}$ para los justos, en cambio, la bendición entendida como salvación y paz inmensa en una larga vida, la fecundidad de su simiente con todas las bendiciones perdurables, el gozo en vida sempiterna ${ }^{184}$ después de una resurrección entendida como un revivir los justos a una existencia maravillosa en la tierra. 185

Tal es el modo de ver que subyace al pensamiento de una comunidad que se concibe a si misma como la sania comunidad de los elegidos, en razón de la cual se crearon el mundo, los pueblos y los hombres; pero que, por su parte, ha perdido la relación con el mundo, los pueblos y los hombres y deposita sus esperanzas de salvación en un acontecimiento que pondrá fín al estado actual del mundo, producirá un nuevo estado cósmico maravilloso, con un nuevo cielo, que pertenecerá a los elegidos de Dios! ${ }^{166}$

Asi sinteriza Grundmann la realidad esenia y las consecuencias de su elitismo y separación del mundo.

\section{Diferencia entre los distintos partidos}

Lo que hay detrás de las diferencias y tensiones entre estos grupos dirigentes es la posición que cada grupo (iene ante la escatologia y la apocaliptica, por lo cual se dividen en dos grandes bloques: en un lado están los fariseos, los zelotas y los esenios, bajo cuya teologia subyace el pensamiento apocalíptico; en el otro los saduceos, con una posición decididamente antiapocaliptica e interesadamente conservadora.

La apocaliptica es una teologia comprometida, no evasora de la realidad, que esıá convencida de la inminencia del fin del mundo y trata de descubrir las señales del úlıimo dia; con eso pretende despertar en sus fieles la capacidad de decisión en favor del reino frente al final. El retraso de éste confirma a los saduceos en el esceptismo, pero en los demás provoca la pregunta sobre qué queda aún por hacer para acelerar el fin. 
Cada grupo va a responder de manera diferente a esta pregunta, a la cual subyace una triple problemática: qué es de la fidelidad de Dios al pueblo y de la acción que lo ha de liberar de la miseria presente; quién es el destinatario de la salvación; cuál es la colaboración que el hombre ha de dar a la llegada del reino; este último punto incluye la cuestión del mesias. Veamos las respuestas que cada grupo da a codo esto.

Todos los partidos responden afirmativamente a lo primero: Dios es fiel y su acción en favor de Israel tiene que ver con la historia. Pero ¿con la historia de quiénes? ¿Con cuál historia? Es el problema del destinatario de la promesa y de la manera cómo esa promesa se realiza en la historia. Cada grupo entiende todo esto desde una concepción exclusivista y excluyente que desplaza la promesa en favor de sus miembros, destinatarios privilegiados (incluso únicos) de la fidelidad de Dios. Desde una perspectiva nacionalista los tres partidos excluyen a los paganos, particularmente a los romanos, quienes son los enemigos a vencer por Dios cuando llegue el reino. "La resistenciá a los ocupantes romanos era, desde los tiempos de Jesús, el problema por excelencia de Palestina, problema a la vez religioso y político." 187 Pero curiosamente los menos violentos conira los romanos (los fariseos y, en su grado, los esenios) son quienes más violenta y abiertamente rechazan a los pecadores y al pueblo sencillo e ignorante. Los zelotas no rechazan abiertamente al pueblo pero, aunque realizan algunas acciones reivindicativas como la quema de los archivos de deudas, más parecen buscar el apoyo del pueblo que mirar por los intereses de ésıe.

Los saduceos, conservadores de la tradición juridica escrita, no reconocen el mismo valor a codos los libros santos y no dan, en la práclica, ninguna importancia a las esperanzas mesiánicas contenidas en los profetas: menos aún en los posteriores escritos o tradiciones. Sólo vale la Torah como norma, la cual interpretan desde una concepción materialista e inmanente de salvación orienlada a la posesión de la tierra; por ello consideran su prosperidad personal como prueba del cumplimiento de las promesas; lo único que hace falta para mantener eso es el culto y la observancia de la Toral sin los extremismos y novelerias fariseas y esenias. Aceptar uri reino futuro y las ideas mesiánicas inherentes provocaria una reacción represiva de parte de los romanos; eso traeria como consecuencia la pérdida de su situación privilegiada. Por otro lado, aceptar la resurrección y una retribución posterior supondria poner en cuestión su privilegio presente y su situación de bendición. Esto explica la reacción violenta de los sacerdotes contra cualquier pretensión mesiánica $y$, concretamente, conira Jesús.

Los fariseos, a diferencia de los saduceos, no reconocen legitimidad a la dominación romana; sin embargo, son hostiles a la resistencia violenta, que ellos ven que puede comprometer el estatuto mínimo de autonomia cultural y juridica de lsrael; además creen que sólo Dios será el realizador del reino fuluro; esperan que envie al mesias liberador, a quien atribuyen una dimensión nacionalista, política, por tanto, pero no creen que su venida pueda acelerarse mediante la resistencia armada, sino sólo mediante la fiel observancia de la ley. De hecho, durante la guerra judia se separarán de la resistencia armada, en la 
que si participarán los esenios; después de la destrucción se convertirán en líderes de la reorganización nacional. Esta actitud moderada y de rechazo a la resistencia no es seguro que haya sido vista con buenos ojos por el pueblo; sin embargo, el prestigio que ante él tienen los fariseos es innegable. El pueblo estará tensionado entre las tendencias farisea y zelota.

¿Cuál es la acción que debe realizar el hombre para acelerar la venida del reino de Dios? Los saduceos dirán que ninguna, porque no habrá tal 'venida' de Dios; niegan el reino como ilusión apocaliptica sobre la cual no hay nada dicho en la Torah; asi pretenden sofocar las tensiones que nacen de esa expeclativa, matando, al mismo tiempo, la esperanza del pueblo.

Los fariseos consideran que la contribución al reino está en la agudización de la pureza y en la observancia rigurosa de las leyes. "Algunos rabinos creian, por ejemplo, poder aproximar los dias del mesias y con ellos la redención, es decir, acelerar su 'venida' mediante la penitencia, el cumplimiento de los mandamientos, el estudio de la Toralı y las buenas obras." 188 "En la creencia de que el reino venidero de Dios dependia de la conducta de los hombres se manifestó la tendencia activa y no fatalista del fariseismo. Sin perjuicio de la soberanía de Dios, corresponde a los hombres una cooperación en la erección del reino." 189 Pero esa actitud de radicalización de la pureza agudiza también la contradicción ideológica entre puros e impuros, entre elegidos y excluidos, entre quienes tienen méritos y quienes no los tienen; en el fariseismo aparece claro el dinamismo excluyente de la ideologia de la pureza.

Los zelotas movilizan su fuerza y al pueblo en función de agudizar la contradicción politica desde la guerrilla abierta contra los romanos, esperando que ello provoque la intervención de Dios para salvar a su pueblo; mediante ella pretenden mostrar a Dios su disposición y su conversión, su yahvismo militante. En cambio, los esenios piensan que lo que hay que radicalizar es la expectación pasiva de la decisión de Dios, desde la fidelidad nimia en la pureza, en lavatorios, en conocimiento de la ley de Dios, como preparación para la guerra escatológica futura a la que Dios los convocará.

En cuanto a la espera del mesías es difícil reducir a unos cuantos rasgos las expectativas que habia; intentaremos resaltar los aspectos en torno a los cuales se dan las divergencias.

Una primera fuente de divergencias será la distinción entre reino de Yahvé y reino del mesias. Siendo la primera la idea dominante, no implica necesariamente la intervención de un mesias. ${ }^{190 \mid}$ Mowinckel hace notar que resulta significativo que la literatura sapiencial no se ocupe del mesias; señal de que había círculos para los cuáles eso no resultaba significativo. La presión de las situaciones malas hacia revivir el anhelo por un libertador, pero en gran parte de la literatura rabínica aparece con claridad el aspecto fundamental del reinado de Dios, cuyo dominio sobre el mundo se da en la sumisión del hombre a la ley. 19ll Otros esperarán directamente la intervención de Dios. Una acción del meslas es vista, en todo caso, como un interregno antes del definitivo dominio de Dios, pero distinto de él; algo intermedio entre los dos "eones," el histórico 
y el definitivo. Esta concepción evolucionará hacia los "milenarismos," doctrinas sobre el tiempo mesiánico aqui en la tierra.

Otras diferencias se darán en cuanto a la manera de entender al mesías: mientras los zelotas ( $y$ en parte los fariseos) esperan un mesias davídico, más políico para los primeros, más religioso para los segundos, los esenios esperan dos mesias, uno sacerdotal, primero en dignidad, y otro real, inferior al primero; a ambos los precederá el profeta escatológico. Para los samaritanos será un hombre mortal (el $t a$ 'heb) y su reinado será seguido por otro superior. Se considerará también como mesias a algunos personajes del pueblo (como es el caso de los múltiples mesias, mencionados anteriormente, al hablar de la Pax romana). Finalmente, algunos lo revestirán de rasgos celestiales, incluso la preexistencia.

Asi, pues, la idea del mesias ha variado de importancia dentro de la devoción hebrea. Nació como un aspecto particular de la noción del reino de Dios, pero gradualmente se separó de la misma por un camino que condujo al concepto del interregno. Siempre ha conservado su indole mundana, nacionalista y política, aun cuando se la asociara a una concepción universalista del reino de Dios sobre la tierra, como sucede en el moderno judaismo ortodoxo. Nunca ha sido la expresión natural del aspecto esencialmente religioso del reino de Dios. Por esa razón la relación de las dos ideas varió en determinados momentos. La creencia en el mesías tuvo mayor vigencia en tiempos de opresión y de zozobra nacional, política y reljgiosa... Solamente en algunos circulos apocalipticos del judaismo tardio alcanzó esta idea una importancia vital y una posición central. ${ }^{192}$

Pero aún hay que considerar un elemento más que intensifica estas tensiones entre los partidos judíos, y que será fundamental para analizar la práctica de Jesús: la oposición centro-márgenes, que en el evangelio de Marcos está simbolizada en la oposición Jerusalén-Galilea; estos dos "lugares" no son un simple escenario geográfico neutro, sino dos campos geo-religiosos contrarios.

A lo largo de toda la historia de lsrael se constata un enfrentamiento sur norte. Jerusalén fue en la historia judía (y lo sigue siendo en tiempos de Jesús) el centro judío por excelencia. Sede de la monarquía, del templo y del culto, lo será también de las principales escuelas de interpretación de la ley (escribas y fariseos) y también del comercio necesario para el culto. Pero su indiscutible centralidad religiosa, ideológica, política y económica no ha sido obra del azar ni de una situación geográfica privilegiada, ni la mera "elección" de Yahvé, sino que ha sido resultado de conflictos incluso armados, tanto hacia dentro del pais judío como hacia afuera, y también de manipulaciones ideológicas de los grupos dirigentes.

Internamente la centrajidad de Jerusalén ha sido resultado de la dominación sobre las tribus del norte (en tiempos de Salomón y Roboam), de las intrigas cortesanas, de la actividad ideológica yahvista (J) y sacerdotal (P), de la primacia de los sacerdotes sadoquitas sobre los levitas (en tiempos de la reforma yahvista de Josias), de la centralización del culto y la inflación de la pureza 
(después del destierro), con su consiguiente acumulación económica en torno a las actividades purificatorias-sacrificiales.

Hacia el exterior, Jerusalén fue centro de la resistencia contra los imperios extranjeros. El espiritu de esa resistencia era la fe en el dominio exclusivo de Yahvé sobre el pueblo y la esperanza en la fidelidad de Dios; resistencia que tuvo muchas facetas: pasiva durante el destierro; politica y negociadora en vistas al retorno; creativa durante la reconstrucción; sufriente durante las persecuciones religiosas; violenta en el alzamiento macabeo.

Ahora está a flor de piel, en liempos de Jesús, contra el imperio de turno, Roma, pero Jerusalén ya no es el centro de esa resistencia, que ahora se da en la periferia. En ello han influido, sin duda, las concesiones de privilegios que los romanos conceden a sus habitantes. Por ello predomina en Jerusalén una tendencia conservadora militante.

Ahora bien, hablar de centro supone como correlato hablar de márgenes; hay centro porque y en la medida en que hay márgenes. Respecto de Jerusalén hay una doble marginalidad correlativa: una interna (centro de poder-pueblo) y otra externa (Jerusalén-resto del pais, particularmente Samaria y Galilea, es decir, el norte). Los evangelios dejan constancia de la actitud de desprecio que habia de parte de los judios respecto de los samaritanos y de los galileos. Y este desprecio se basaba en consideraciones referentes a la impureza que, según las categorías fariseas, afectaba a los habitantes de ambas regiones. Samaria representaba la historia del reino del norte y de sus reyes e idolatrias. Cuando el primer destierro, permanecieron en el territorio del norte muchos campesinos, junto con ocupantes asirios. Al retorno del exilio de Babilonia, samaritanos que permanecieron fieles al yahvismo, y que habian seguido teniendo a Jerusalén como centro religioso, se ofrecieron a ayudar a la reconstrucción del templo, pero fueron rechazados por los judios como impuros e indignos de participar en dicha reconstrucción; entonces pasaron al ataque y se opusieron a la reconstrucción tanto del templo como de Jerusalén, incluso con gestiones ante el rey persa (cf. Esd. 4); después de eso siguieron fieles al culto a Yahvé en el monte Garizim. Galilea ha sido siempre lugar de paso y de comercio; cuenta con la mejor situación geográfica para la agricultura y tiene también el lago para la pesca; pero está en contacto con los "paganos" y se ha mezclado con ellos; por eso es considerada por los judíos como la "Galilea de los gentiles" y nada bueno se espera que salga de ahi. Y precisamente en ella liene su origen el movimiento zelota.

Como se ve, en esta relación tensa entre el centro y los márgenes hay motivaciones de todo tipo; políticas, económicas, religiosas. La "geografia" no es un mero telón de fondo, sino un actuante en la historia; Jerusalén, Galilea y Samaria tienen una significación geo-religiosa, geo-teológica. En los relatos de Marcos y Lucas, Galilea es el lugar de la práctica de Jesús; en Marcos y en Mateo, Galilea es el lugar del reconocimiento de Jesús después de la resurrección; Jerusalén es el lugar de la negación de la práctica de Jesús, a quienes desautoriza y condena a muerte; Jesús, a su vez, desautoriza a Jerusalén y al templo y 
los condena a la esterilidad. Este es el fondo teológico de una dinámica creciente de marginación sociopolitica y religiosa en que vive Jesús, el galileo.

¿Y todo esto para qué?

Dice atinadamente Hugo Echegaray:

Que esta humanidad (de Jesús) tuvo todos los caracteres de una humanidad real no es sólo el presupuesto de este trabajo, sino también un punto fundamental del dogma cristológico que, por otro lado, no basta con enunciar formalmente. Es necesario explorarlo en su significación precisa... sin olvidar que la divinidad se ha inscrito en rasgos inefables en la humanidad humilde de Jesús. ${ }^{193}$

Hemos abordado la problemática sociohistórica del tiempo de Jesús, así como sus antecedentes, no como dato sociológico, sino como dato teológico. Porque la situación condicionó y configuró la respuesta de Jesús, es decir, la respuesta de Dios al pobre. Su "sí" al hombre no es un "sí" abstracto y desituado, carente de configuración histórica. Fue respuesta al clamor concreto del pobre para el que el mensaje de Jesús fue buena noticia. De ahí la dimensión teológica de la situación sociopolitica y económica de su tiempo: es clave hermeneutica para comprender la práctica de Jesús como salvifica, y también es clave hermenéutica para normar y definir el "seguimiento" de Jesús en el "pro-seguimiento" de su causa. Así como la dimensión histórica no es algo "optativo" para el hombre, sino algo que le es dado y que lo configura ("yo soy yo y mis circunstancias"), asi es ineludible el conocimiento de las circunstancias de Jesús para comprender su respuesta-en-situación; y luego será ineludible, para el "seguimiento" correcto, el conocimiento de nuestra propia situación para poder hacer, en el Espíritu de Jesús, el discernimiento de en qué consiste hoy seguirlo. "La práctica de Jesús, por ser la de un agente histórico, no manifiesta su sentido, sino resituyéndose al conjunto de condiciones objetivas de su tiempo, de orden económico, social, político y cultural de las que muchas veces se la ha aislado. Como toda práctica humana, la de Jesús no representa un comienzo absoluto ni es comprensible sólo a partir de sí misma. Cristo tuvo que intervenir en un campo de fuerzas ya creado, de interacciones y conflictos que no dependla de él configurar o evitar, y en relación a los cuales tuvo, en consecuencia, que definirse." 194 Con este estudio queremos contribuir a aquello que seftala Ignacio de Loyola como finalidad de la contemplación de la vida de Jesús en los Ejercicios: el "conocimiento interno del Señor, que por ml se ha hecho hombre, para que más le ame y le siga." 195

\section{Notas}

1. Las princlpales obras consultades pare este estudlo son J. Jeremlas, Jenusalem en tiempas de Jós; Leipoldt y Grundmenn, El mundo del Nuevo Testamento; Schultz (ed.), Jeris y su Hempo; Thelssen, Sociologia del movimiento de Jesis; Orelot, L'esperdnce jutve a l'heure de 
Jesús; Derret, Jesus' Audience Cullmann, Jesus y los revolucionarios de su tiempo, y Dieu et César; H. Braun, Jesús, el hombre de Nazaret y su tiempo, y Jesús y la violencia revolucionaria; Saulnier y Rolland, Palestina en tiempos de Jesús; Bowker, Jesus and the Pharisees; Le Moine, Les Saducées; J.I. González Faus, Jesús de Nazaret y los ricos de iu tiempo; Echegaray, La práctica de Jesús; F. Belo, Lectura materialista del evangelio de Marcos; Clevenot, Lectura materialista de la Biblia; A. Paul, El mundo judio en tiempos de Jesús; Ch. Perrot, Jesuis de Nazaret y la historia; Bornkamm, Jesús de Nazaret; J. Blank, Jesús de Nazarel; Greeley, El mito de Jesuis.

2. Una advertencia respecto de este análisis, al incluir en la instancia ideológica lo religioso y al asignarle a esa instancia una actividad de "producción" de esos elementos arriba descritos, no se prejuzga, ni menos se niega, el hecho de la revelación; por el momento el análisis se cihe al aspecio humano de la producción de las leyes o de los sentidos, es decir, a la vertiente sociológica del renómeno religioso-moral.

3. Cir. Jeremias, oc. 244: Theissen, oc. 42.

4. Jeremias, oc., 110-113.

5. La base de esıa presentación son los dos primeros capitulos de la obra de Jeremias, 19-74.

6. Jeremias, oc., 317.

7. lb. ib., 320-322.

8. Id. ib., 317, 322 .

9. Id. ib., 322-323.

10. Id. ib., 131-138; Clr. González Faus, oc., 18-20; L. Schottroff, "Pobres y ricos en los evangelios sinópticos," Sal Terrae, 88. 279-282.

11. Ant. XX 8,8; 9,2; cfr. Jeremias, oc., 116.

12. Theissen, oc., 54.

13. Jeremias, oc., 139-142. Hay productos que llegan a costar de 3 a 6 veces más en la ciudad que en el campo; el incremento del cosio de artículos de primera necesidad llegó, en tiempos de calamidad, a aumentar en un 1.600 por ciento (142).

14. Jeremias, oc., 143-145; Theissen, oc., 44.

15. Jeremias, oc., 109.

16. Id. ib., so; un par de palomas para el sacrificio del pobre llegaron a costar dos denarios de oro. es decir, 50 denarios de plata, el equivalente a 50 dias de trabajo.

17. Theissen, oc., 42.

18. Id. ib., 43.

19. Jeremias, oc., 280; sobre la pobreza de los sacerdotes por causa de la voracidad de los sumos sacerdotes ver id., $116 \mathrm{~s}$.

20. Id. ib., 144, notas 40 y 41 .

21. Cfr. Gonzalez Faus, oc., 20.

22. El nacimiento de Jesús es común situarlo hacia el 6 o 7 a.C.; ver Biblia de Jerusalen, cronologla; Charpentier, Para leer el NT, Leipoldt y Grundmann, oc., I, 511.

23. Leipoldt y Grundmann, oc., $1 / 4$.

24. Jeremias, oc., 27 y 72.

25. Bell, 2, 328; Theissen, oc., 67.

26. "La actitud moderada de los jerosolimitanos se apoyaba en intereses comunes del pueblo y la aristocracia en el stalu quo de la ciudad y templo... La población ciudadana de Jerusalen no pudo interesarse por semejantes cambios" (Theissen, oc., 53). Pero me parece que extiende inadecuadamente a todo el pueblo la oposición de los movimientos de resistencia contra el templo, ignorando que el sentimiento popular tiende fácilmente a aceptar la legitimidad de lo religioso oficial; su a irmación es razonable si se refiere soblo al movimiento zelota en tiempo de la guerra judía, y como dirigida más contra la clase sacerdocal dominante que contra el templo.

27. Theissen, oc., 54.

28. Id. ib., 49.

29. Virgilio, Egloga IV; Inscripción de Halicarnaso; Veleyo Paterculo, Historia romana, II, 89; Res gesiae divi Augusti, 12; Horacio, IV, 5.

30. Leipoldt y Grundmann, oc., 176.

31. Hengel, oc., 65s.; subrayado mío. 
32. Ant. XIV, 225-227; XVI, 162-165; Cfr. Leipoldt y Grundmann, oc., 178s.

33. Jeremias considera que las cargas fiscales permanecen probablemente identicas hasta el 66 d.C. Si el talento equivale a 10.000 dracmas (109), y estas tienen un peso de 4.36 gramos de plata (Biblia de Jerusalén, 1648), el talento andará por los 43 kilogramos de plata (Cfr. Haag, Diccionario blblico). La Biblia de Jenusalen senala también otra equivalencia: un talento es igual 34.272 kilogramos, aunque sin decir cuál es la base de su cálculo. Obviamente no se pueden der equivalencias correctas, pero bastan para comprender lo duro de las cargas impositivas que pesan sobre la población judia, ye nada más por el concepio del impuesto romano. Quizás una aproximación más práctica se pueda hacer en base a la equivalencia existente entre dracma y denario, el equivalente del salario de un dia de trabajo: 600 talentos equivaldrian a 6 millones de salarios-dia. Flavio Josefo habla de que en poco tiempo tuvieron que pagar los judios la cantidad de 10 mil talentos. Cfr. Ans. XIV, 4,4-5.

34. Saulnier-Rolland, Polessina en tiempos de Jesús, 17.

35. Id. ib.

36. Jeremias, oc., 145.

37. Bell, 11, 17; cfr. Jeremias, oc., 244.

38. Saulnier-Rolland, oc, 17.

39. "Los romanos poseian el poder militar para imponer sus exigencias en materia de impuestos, la aristocracia sacerdotal tenia recursos ideológicos para cobrarlos... Por la competencia mutua de los dos sistemas de impuestos quedó constantemente en duda la legitimidad de los impuestos estatales. La dualidad de los impuestos pudo ser ya de por sl gravosa, pero su ilegitimidad tenia que provocar la rebelión. La problematica de la legitimidad empalmó inmediatamente los problemas económicos con los religiosos y, por tanto, con el problema de la soberania de Dios y de la elección del pueblo. La situación econónica se interpretó a la luz de esa tradicion." Theissen, oc., 45 s.

40. Ant. XVII, 11,2; cfr. Jeremias, oc., 110.

41. Anr. XVI, 5,4; cfr. Jeremias, oc., 143.

42. Leipoldt y Grundmann, oc., 143.

43. Theissen, $o c$, , 46.

44. Hengel, oc., 66.

45. Jeremias, oc., 241; Theissen, oc., 70.

46. Jeremias, oc., 109.

47. Cfr. supra, nota 33.

48. Hengel, oc., 66.

49. Theissen, OC., 72. Parece haber habido un culto incipiente a Herodes en Sl'a, Transjordania; es clara en él una búsqueda constante de homenajes que lo envuelvan en una aureola sobrehumana. Busca aparecer como el anunciador de la salvación imperial romana en Judea. "En el centro mismo de esta concepción herodiana del mesianismo se encontraba Herodes como descendiente de David... el árbol genealógico del rey, de acuerdo con la antigua practica, se hizo davidico... Esta concepción... debla suministrar al reinado herodiano la legitimación judeo religiosa de que carecla. No cabe duda de que representaba una inaudlta provocacibn a las esperanzas religioso-necionales del pueblo judio." A. Schalit, en Schultz (ed.), oc., B6s.

50. Leipolde y Grundmann, Oc., 200.

51. Ant. XVII, 293s.; Bell, 11, 73s.; Cfr. Hengel, oc., 69; Biblla de Jerusalen, 1674.

53 Jeremias, Oc., 100.

54. $A$ nt. XVII, 278-281; citado por Hengel, oc., 69.

55. Leipoldt y Grundmann, oc., 178.

56. Hengel, oc., 69.

57. Hay muchas dudas sobre la datación del censo de Quirinio; parece probable un censo iniciado alrededor del 7 a.C. y terminado alrededor del 6 d.C. y organizado en dos etapas: el registro (apografe) y la recaudación (apotimesis). Cfr. Leipoldt y Grundmann, oc., 177. Perrot objela la datación del ejercicio de Quirinio en esa fecha temprana y dice que aún no está re. suelto el problema, ofr. Jesis y la historia, 72.

58 Hengel, oc., 20 y 74.

59. Leipoldt y Grundmann, oc., 182.

60. Hengel, oc., 74. 
61. Leipoldı y Grundmann, oc., 179: Schultz (ed.), Jesús y su tiempo, 21.

62. ld. $i b$.

63. Citado por Hengel, $O c, 77$.

64. Leipoldi y Grundmann, oc., 179.

65. Hengel, oc., 77.

66. Theissen, oc., 63s.

67. Hengel, oc., 77.

68. "Aumentaba su indignación el hecho de que los judios fueran los únicos que no habian cedido" Schultiz (ed.), oc, 91.

69. Id. ib., 89.

70. La importancia de este hecho se comprende leyendo to que significaban los ornamentos para cl culto: debe usarlos el sacerdote para no incurrir en culpa y morir (cfr. Ex. 28,43). Es algo que sollo puede usar el sacerdote. Todo el capilulo 28 del Exodo nos hace entrever el atentado que implica esta medida romana de control.

71. Leipoldı y Grundmann, oc.. 178s.

72. Jeremias, oc., 244.

73. Olibeira Leite Goncalves, Cristo e a contestacao pollica, 40; cita a Klausne, Jesus of Nazaret, 167.

74. Debc usarse moneda judia para todo el comercio en torno al templo; en cambio el impuesto a Roma es en moneda romana. De ahi la necesidad de esos intermediarios (Cfr. Lohse, en Schulız (ed.), oc., capitulo 9.

75. Cfr. Jeremias, oc., 244, 114, 121; Leipoldt y Grundmann, oc., 201; Hengel, oc., 76; Echegaray, La próctica de Jesús, 70-71; Theissen, oc., 45.

76. Leipold y Grundmann, oc., 198.

77. El comercio de animales constituyó probablemente una de las entradas económicas sustanciales de la familia de Anás. Cir. Jeremlas, oc., 65, 117; Hengel, oc., 76.

78. Leipoldı y Grundmann, oc., 199.

79. Cfr. Jeremias, oc., 116s., 176s., 211s., Pes. 57a, citado por Bowker, Jesus and the Pharisees, 139.

80. Se trata de los textos en que Yahve "cede" sus "diezmos" como heredad a los hijos de Levi: "Tú no tendrás parte en la heredad de su tierra... Yo soy tu parte y tu heredad.. Y doy como heredad a los hijos de Levi todos los diezmos, por el servicio que preslan... Los hijos de Israel no han de acercarse ya más al tabernáculo de la reunión, no lleven sobre sl su pecado y mueran... No tendrán heredad en medio de los hijos de Israel, pues yo les doy por heredad las décimas de lo que los hijos de Israel han de entregar a Yahve" (Num. 18, 20-32); "si alguno quisiera rescatar parte de su décima, habrá de añadir el quinto" (Lev. 27, 30s.). El mismo lexto de Di. 14, 22-26 necesitará ser interpretado por una exégesis "interesada" para descubrir la obligación de dos diezmos: después de habler del diezmo en especie, dice: "Pero si el camino fuese largo para poder llevarlos allá, por estar tú demasiado lejos... lo venderás tomando el dinero en us manos, iras con él al lugar que Yahvé, iu Dios, elija. Alli comprarás con el dinero lo que desees... y comerás alli, delante de Yahvé, y te regocijarás tú y tu casa. No dejarás de lado al levita que mora en lu ciudad" (Cfr. Jeremias, oc., 153); a costa de la ley los comerciantes harán su propaganda, con una motivación consumista-religiosa: "vengan y compren las especies que exige la ley" (Cfr. Jeremias, oc., 121, nola 26, el subrayado es mio). Sobre el segundo diezmo ver id., 45; 63 (nola 151), 75s., 121, 148, 153-156, 185.

81. Tomando los cálculos más conservadores de Jeremias (95-102), quien habla de unos 30 mil habitantes fijos y unos 100 mil peregrinos durante la pascua, sólo estos aportarian al tesoro del templo, por el conceplo del impuesto de la didracma, une cantidad superior a la tonelada de placa, o el equivalente a 260 mil salarios-dia. Pero hay que tener en cuenta además que ese impuesto obliga a todo judio, incluida la diáspora (Jeremias, oc., 74); Leipoldı y Grundmann calculan la población total en unos 4 o 6 millones de judios residentes en el extranjero, más un millón y medio o dos en Palestina (oc., 307s.); si realmente lo pagaran todos, aportarlan una cantidad cercana a las 70 toneladas de plata, o 16 millones de salarios-dia.

82. Jeremias, oc., 75 s., 153.

83. Id. ib., 23.

84. Id. ib., 109.

85. Flavio Josefo presenta una cifra de 255.600 victimas; Bell, VI, 9,3. 
86. Jeremias, $O C$., 74,

87. Id. ib., $221 \mathrm{~s}$.

88. Id. ib., 30 y 39.

89. Cfr. Theissen, oc., $51-53$. Las circunstancias condicionan la actitud polílica y religiosamente conservadora de la capital; su causa pudo estar en la variedad de intereses materiales que tenian a toda la población pendiente del templo. Esı́a vinculación creó un parcial acuerdo de intereses entre las capas alıa y baja de la sociedad. Casi Iodos Ios jerosolimitanos dependian indireciamente del templo. Una parıe insignificante de la población dependia directamente de èl; además, el templo ofrecia venlajas juridicas a toda la ciudad, como la dismisnución de impuesios.

90. Jeremias, oc., 49 y 140

91. Ker., 1, 7.

92. Jeremias, oc., 50.

93. Leipoldt y Grundmann, oc., 202. "El jornal medio de un denario de plata venia a cubrir aproximadamente las necesidades minimas de una familia reducida. De no encontrar trabajo en varios dias, el jornalero quedaba en la miseria más absoluta."

94. "En el año 64 a.C. un huracán destruyó coda la cosecha hasta el punto de que el modium de (rigo fue vendido entonces a 1$]$ dracmas. O sea, por once dracmas adquirieron 8.752 litros, al precio de 0.796 litros por dracma; mientras que en épocas normales se adquiririan 13 liıros por dracma. Asi que los precios se multiplicaron por 16," Jeremias, oc., 142.

95. "Un habitante de una pequerta ciudad que se casase con una joven de Jerusalén le daba el peso de ella en oro; y una joven de una pequeña ciudad que se casase con un hombre de Jerusalén le aportaba el peso de él en oro," $\operatorname{Lam}$. $R ., 4,2$, citado por Jeremias, oc., 140.

96. Jeremias, oc., 137; Leipoldt y Grundmann, oc., 202-204.

97. Jeremias, oc., 156: Theissen, oc., 51s.

98. Koch, en Jesús y su tiempo, 113. La analogia con los partidos obviamente no debe extrapolarse, pero es válida en lo fundamental.

99. Cfr. 1Qp Hab, V, 8-12, texto en Leipoldt y Grundmann, II, 186.

100. "Los sumos sacerdotes saduceos estaban obligados, aun contra su voluntad, a realizar las ceremonias litúrgicas según la explicación farisea de la Torá... La vieja generación de los saduceos mostró una total resignación, pues comprendian que era imposible triunfar del poder omnlmodo de los fariseos... Cuando llegan a las magistraturas se acomodan (los saduceos) a las prescripciones de los fariseos, por necesidad y contra su voluntad, pues de otro modo el pueblo no los soportaria," Ant., I, 4; cfr. Jeremias, oc., 279. "Tienen tanta infuencia (los fariseos) que, cuando dicen algo contra el rey o contra el sumo sacerdote, inmediatamente encuentran credito," Ant., XIII, 10, 5.

10l. Leipoldt y Grundmann, oc., 285.

102. Jeremias, oc., 280.

103. Id. ib., 262, 266s.

104. Sifro Lev. 11, 44-45; cfr. Jeremias, oc., 264, nota 23; cfr. Lev. 20, 26.

105. Leipoldt y Grundmann, oc., 285s.

106. Id. Ib., 285.

107. Id. Ib., 287.

108. Cfr. Jub. 50, 6-13; Syllabus de los 39 abot, texto en Leipoldt y Grundmann, II, 243.

109. Leipoldt y Grundmann, oc., 287s.

110. Existe un "notorio desequilibrio enere la confianza en la misericordia de Dios y la confianza en la propla Justicia... Creencia en Dios y confianza en si mismo," id. ib., 292, citado en Braun en su estudio sobre los Salmos de Salomón.

111. "El ignorante no se arredra ante ningún pecado y el am-ha-eres no es piadoso" ( $P$ ir $A b$ 2,5); "de quien no tiene conocimiento alguno no hay que compadecerse"' (Midr a Sam 9); cfr. Jeremias, oc., 273s.; cfr. Leipoldt y Grundmann, oc., 293.

112. "Quien tiene el proposito de ser un haber (miembro de una hermandad farisaica) no debe comprar frutos húmedos ni secos a un am-ha-erez, ni tampoco adquiere de el frulas del tiempo; esimismo no se aloje en su casa como húesped ni da hospitalidad en la suya a un hombre con su atavlo" (Demai 2,3), cfr. Leipoldt y Grundmann, oc., 298.

113. TB Baba Batra 8a.

114. TB Ket $111 \mathrm{~b}$. 
115. TB Baba Barra 10,a.

116. $T B$ Sab $118 \mathrm{~b}$.

117. CIr. Grelot, L'espérance juive á /'heure de Jésus, capitulos 3 y 5.

118. Winier en Jesús y su tiempo, capitulo 6.

119. Abot Rab. Natán 5, cfr. Leipoldt y Grundmann, oc., 281.

120. Leipoldi y Grundmann, ib.

121. $A n t$ XIII, 10,6.

122. Amt. XVIII, I,4, cfr. Jeremias, oc., 245.

123. Leipoldt y Grundmann, oc., 281.

124. "Y ellos se servian diariamente de utensilios de plata y oro (porque negaban la resurrección de los muertos, y por ello, querian gozar de la vida terrena lo más posible)." Asi resume Jeremias la siluación que describe Jose To ( $A n t$. XIII, 10,6). Y continúa: "Es exacto que los partidarios de los saduceos pertenecian a los ambientes acomodados. Recordemos, finalmente, que en la teologia de los saduceos y ell su postura ante la vida se notan influencias helenisticas; lo quc apunta también a los ambienıes con fortuna. pues fueron éstos los más influidos por la cultura helenistica," Jeremias, oc., 245, nola 56. Según Winier es probable que el libro del Eclesiastés, con toda su visión pesimista y materialista de la vida, tenga por autor a un saduceo, cfr. Schuliz (ed.), oc., capilulo 6.

125. Jeremias, oc., 172.

126. id. ib., 247s.

127. Cfr. Mc. 4, 18-19. En el análisis que Jesús hace de las diferentes respuestas anıe el mensaje habla de que la riqueza y las codicias de todo tipo oprimen la palabra sobre el reino y no la dejan dar fruto. ¿Podrá estar teniendo en cuenta a los saduceos en este análisis?

128. Grelol, oc., 265.

129. Ecliegaray, La prácrica de Jesús, $102 \mathrm{~s}$.

130. Hengel, oc., 76.

131. Bell, 11, 338.

132. Theissen, oc., 57; Echegaray, oc., 81.

133. Jeremias, oc., $211 \mathrm{~s}$.

134. Leipoldi y Grundmann, oc., 208; Berret, Jesus' Audience, 46:

135. Jeremias, oc., 176s.

136. Leipoldt y Grundmanı, oc., 206.

137. Jeremias, oc., 179.

138. Tos., citado en Jeremias, oc., 213. Alli aparecen más textos del pueblo contra las familias sacerdoiales.

139. Anás durará del 6 al 14 d.C.; Cajfás, su yerno, del 18 al 37; sus cinco hijos serán sacerdotes; su gran riqueza vendrà del comercio de animales para el sacrificio (cfr. Jeremias, oc., 65 y 117; Berret, oc., 46; Hengel, oc., 76; Amt. XX, 198). I

140. "La misná habla de diez grados de sanidad: estaban situados en circulos concéntricos alrededor del Sancta Sançorum: 1. El pais de Israel. II. La ciudad de Jerusalén. III. El monte del templo. IV. El "jel," terraza con una balaustrada que la separaba del resto de la explanada del templo; esta balaustrada marcaba los limites permitidos a los paganos. V. El atrio de las mujeres. VI. El atrio de los israelitas. VII. EI atrio de los sacerdotes. VIII. El espacio entre el altar y los holocausios y el edificio del templo. IX. El edificio del templo. X. El Sancia Sanctorum... Lus circulos VIII. IX y X... pertenecian al atrio interior; pero en ningún caso eran accesibles a los laicos..." Jeremias, oc., oc., 965 .

141. Id. ib., 169.

142. Id. ib.

143. Clr. por cjemplo Bell II, 13,2-4.

144. Leipoldt y Grundmann, oc., 301.

145. Hengel, oc., 70.

146. Leipoidt y Grundmann, oc., 301.

147. "El rechazo del censo les granjeó la adhesión de los pobres, de los pequeños campesinos y terratenientes, en tanto que los grandes terratenientes se aliaron con los romanos. La economia estaba en ruinas desde la época de Herodes; los pobres se resentian de ello, los pequeȟos campesinos temian por su tierra. Tenian que tomar préstamos e hipolecar su finca, hasta que ésta caía en manos de los grandes terratenientes y de sus arrendatarios, los cuales, 
por su parte, estaban en connivencia con los cobradores de impuestos del gobierno romano... La corrupción económica bajo los últimos gobernadores romanos cooperó decisivamente al estallido de la guerra judaica," Leipold y Grundmann, oc., 303.

148. Las imágenes del emperador eran las que producian mayor escándalo, "algunos exageran los preceptos hasta el extremo de no tocar ni siquiera una moneda. alegando que no es licito no mirar ni fabricar imágenes" (Hipólito, Ref., IX, 26, citado en Leipolda y Grundmann, oc., 302).

149. Ver Hengel, oc., 70s.

150. Ver Leipoldi y Grundmann, oc., 303; Hengel, oc., 73.

151. "Para los celoras, la conversión consistia precisamentc en un solidarizarsc con la acción revolucionaria, lo cual exigia la disposición incondicional para la propia entrega y aun para el martirio," Hengel, oc., 71, nota 66. Al autor le parece percibir el peligro de que la teologia de la revolución se oriente hacia un "agudo judaismo celoı:" dentro de la valiosa aporıción que hace sobre la conducta de Jesús ante el problema de la violencia y en la que muestra claramente la diferencia entre él y los zelotas, queda la impresión de que su juicio sobre la violencia de resistencia peca de exceso de teoria y de ignorancia respecto de la angustiosas siluaciones concretas de muchos paises oprimidos, asi como de desconocimiento de la exigen. cia de no neutralidad que se impone a la teología de la liberación en el tercer mundo.

152. Mowinckel, El que ha de venir, 307.

153. Hengel, oc., 72.

154. Mowinckel, oc., 307 y 340.

155. Hay que recordar la represión ejercida contra su población como represalia romana por el levantamiento de Judas, el año 6 d.C., ver Hengel, oc., 69.

156. Hengel, oc., 72.

157. Id. ib., 74.

158. Ver 2Mac. 4, 7-20.

159. Leipoldt y Grundmann, 240s.

160. Ver Grelot, oc., capitulo I.

161. "Si la escatologia profética partia de un plan de Yahvé con la historia del pueblo y la humanidad, dicho plan se convertia en objeto de una determinación especulativa entre los apocalipticos," Leipoldt y Grundmann, oc., 240.

162. Id. ib. 265.

163. Dam, IV, 2; VIII, 16.

164. I QH, IV, 32a.

165. Leipoldt y Grundmann, oc., 264.

166. Id. ib., 273.

167. Id. ib., 271.

168. Id. ib., 270. "Uno de los textos qumramitas trae veintiocho prescripciones de detalle en este mandado," Haag, "La comunidad de Qumrán," en Schulız (ed.), oc., I36. Se trata de Dom, X, 4 - XII-18. El tex10 puede verse en Leipoldt y Grundmann, II, I69-168. Ver también Jub., $50,6-13$.

169. Id. ib., 253.

170. Id. ib., 2545.

171. Ver Grelot, oc., capitulo 2.

172. I QS, VIII, 8s.

173. Leipoldt y Grundmann, oc, 270.

174. Id. ib., 269.

175. I QS, V, 7.11.

176. Ver I QS, V, 14-17.

177. I QS, I, 9-11. Ver Leipoldı y Grundmann, oc., 272.

178. CDC, XII, 23; I QH, VI, 29-33; I QM, 1, 1-12.

179. "Levántate, vencedor, captura tus cautivos, hombre de la gloria. Arrebata tu botin, hacedor de proezas. Golpea en la nuca a cus enemigos y pon tu pie sobre el montón de muertos. Golpea a las naciones enemigas y que tu espada devore la carne pecadora. Llena la lierra de tu gloria y a tus herederos de bendición: rebaños de ganados en tus campos, plata y oro y piedras preciosas en tus palacios" (1 QM, XII, 10-12). También se habla de despojar a los sacerdotes de toda su riqueza, ver 1 Qp Hab, IX, 3-12. 
180. Ver Grelol, oc., capitulo 2.

181. I Qp Hab, VII, 1I-14.

182. I QH, XIII, 13-36.

183. I QS, IV, 12-13.

104. I QS, IV, 6-8.

185. Leipoldt y Grundmann, oc., 276.

186. Id. ib., 239s.

187. Hengel, oc., 16.

188. Schnackenburg, Reino y reinado de Dios, 48.

189. Winier, en Schuliz (ed.), oc., 106.

190. Ver Braun, Jesuis. el hombre de Nazaret y su tiempo, 35.

191. Mowinckel, oc., 370.

192. Id. ib., 374s.

193. Echegaray, oc., 33.

194. 1b. id., $52 \mathrm{~s}$.

195. Ejercicios, 104. 